\title{
SIMILARITY BETWEEN THE DEAD AND LIVING FORAMINIFERAL ASSEMBLAGES OF THE NE SECTOR OF GUANABARA BAY (BRAZIL)
}

\begin{abstract}
Maria Virgínia Alves Martins ${ }^{1,2 *}$, Abilio Soares-Gomes 3 , Cintia Yamashita ${ }^{4}$, Anita Fernandes Souza Pinto 1 , Fabrizio Frontalini ${ }^{5}$, Cristina Sequeira ${ }^{2}$, LaZaro luiz Mattos Laut ${ }^{6}$, Pierre Belart ${ }^{6}$, Noureddine ZaAboub ${ }^{7}$, Paulo Miranda ${ }^{2}$, Silvia Helena de Mello e Sousa ${ }^{4}$, Rubens Figueira ${ }^{4}$, Assane luis Pena ${ }^{8}$, Denise Lara Terroso ${ }^{2}$ AND FERNANDO ROCHA ${ }^{2}$
\end{abstract}

1 Laboratório de Micropaleontologia (LMP-UERJ), Universidade do Estado do Rio de Janeiro - UERJ, Faculdade de Geologia, Departamento de Estratigrafia e Paleontologia. Av. São Francisco Xavier, 524, sala 4037F, Maracanã. 20550 -013 Rio de Janeiro, RJ, Brazil. virginia.martins@ua.pt, anitafspinto@gmail.com

2 Unidade de Investigação GeoBioTec, Departamento de Geociências, Universidade de Aveiro, Campus de Santiago, 3810-193 Aveiro,Portugal.csequeira@ua.pt,pfnmiranda@gmail.com, laraterroso@ua.pt, tavares.rocha@ua.pt

3 Departamento de Biologia Marinha (GBM), Universidade Federal Fluminense - UFF, Niterói, Brazil. abiliosg@id.uff.br

4 Departamento de Oceanografia Física, Instituto Oceanográfico, Universidade de São Paulo, Brazil. cintiasea@gmail.com, smsousa@usp.br, rfigueira@usp.br

5 Università degli Studi di Urbino "Carlo Bo", Dipartimento di Scienze Pure e Applicate (DiSPeA) Urbino, Italy. fabrizio.frontalini@uniurb.it

6 Laboratório de Micropaleontologia (LabMicro), Universidade Federal do Estado do Rio de Janeiro - UNIRIO. Avenida Pasteur 458, Urca, Rio de Janeiro, CEP 22290-240, RJ, Brazil. lazaro.laut@gmail.com, pbelart@gmail.com

7 Institut National des Sciences et Technologies de la Mer Salammbô, Tunisie. nouri_zaaboub@yahoo.fr

8 Universidade Pedagógica - Moçambique, Departamento de Ciências Naturais e Matemática. Rua D. Francisco de Almeida $2^{\circ}$ Bairro, Ponta-Gêa, 2025 - Beira, Mozambique -Caixa-postal: 2025. assanepena@ua.pt

*CORRESPONDING AUTHOR, virginia.martins@ua.pt

Received on 2 November 2016

Received in revised form on 2 December 2016

Accepted on 7 December 2016

Editor:

Lotfi Aleya, Université de Bourgogne Franche-Comté, France
Citation:

Martins, M.V.A., Soares-Gomes, A., Yamashita, C., Pinto, A.F.S., Frontalini, F., Sequeira, C., Laut, L.L.M., Belart, P., Zaaboub, N., Miranda, P., Sousa, S.H.M., Figueira, F., Pena, A.L., Terroso, D.L., Fernando Rocha, F., 2016. Similarity between the dead and living foraminiferal assemblages of the NE sector of Guanabara Bay (Brazil). Journal of Sedimentary Environments, 1(4): 411-431.

\section{Abstract}

Guanabara Bay (GB), located at the coast of Rio de Janeiro State (Brazil), is an ecosystem rich in biodiversity both in terms of mega, macro and microfauna. However, the factors that control their distribution are still poorly understood. This work intends to identify the possible factors affecting the distribution of benthic foraminifera in the bay by comparing living and dead assemblages in selected sediment fractions. Substantial differences in terms of density, diversity and equitability of the species in the living and dead assemblages and in different sediment fractions $(63-150 \mu \mathrm{m}$, 150-250 $\mu \mathrm{m}, 250-500 \mu \mathrm{m})$ are identified. Lower similarity $(<70 \%)$ between the living and dead assemblages are associated with areas impacted by organic matter and may be mainly ascribed to either loss of tests due to dissolution, currents remobilization and abrasion, or inclusion of allochthonous species transported by currents. This work suggests that the use of the living plus dead assemblages or dead assemblages can reduce the accuracy of the results if the work intends to evaluate the environmental conditions.

Keywords: Living and dead foraminifera. Different sediment fractions. Taphonomic effects. Environmental assessment. Coastal system. Guanabara Bay. 


\section{Introduction}

The lack of a systematized database on Guanabara Bay (GB) biota hinders the accurate survey on biodiversity and its change. A recent biodiversity review on GB reported about 1300 taxa cited in the literature (Soares-Gomes et al., 2016). According to these data, $2 / 3$ of the bay biodiversity belongs to the pelagic system and $1 / 3$ of the benthic one. This value, however, is underestimated for benthic organisms because it only accounts macrobentos of the four most studied taxonomic groups in Brazil (macroalgae, mollusks, crustaceans and polychaetas). Most zoological phyla have not been considered in GB, probably due to the lack of taxonomists. Similarly, the benthic microfauna is also quite unknown in GB. Several studies report a spatial gradient in species richness and/or spatial variability in the species distribution on GB (Mendes et al., 2006, 2007; Van der Ven et al., 2006; Santi et al., 2006; Villac and Tenenbaum, 2010; Laut et al., 2011; Gomes and Areas, 2012; Bonecker et al., 2012; Soares-Gomes et al., 2012).

The highest richness values are, in general, recorded in the sector closest to the bay entrance whereas the lowest ones have been observed in the inner sector, where the environmental conditions are more degraded. Although several studies on GB have demonstrated their increasing degradation since the arrival of Europeans (Soares-Gomes et al., 2016), there are no conclusive studies on the effects of various pollutants on the structure and functioning of the biotic communities. This difficulty in establishing a causeand-effect relationship between pollutants and biota is due to a probable case of "Estuarine Paradox" (Elliott and McLusky, 2002; Elliott and Quintino, 2007). The "Estuarine Paradox" arises because the estuaries are places where stresses naturally occur such as saline fluctuations. Regardless of saline stress, the bottom of bays are commonly low hydrodynamic energy environments, which generate a sedimentary gradient between the outer and the internal regions.

Guanabara Bay presents an extensive drainage basin. The largest continental water fluxes occur in the internal region of the bay, where high sedimentation rates are also observed (Figueiredo et al., 2014). Moreover, the occurrence of mangroves in the internal region of the bay contributes to the retention of sediments supplied from the continent (Kjerfve et al., 1997) and to the accumulation of sedimentary organic matter. Studies on GB records show that sedimentation rates varied over the last 6,000 years (Figueiredo et al., 2014). The oldest variations are due to natural causes such as sea level changes. The same study shows however a steady increase in sedimentation rate since
1922, with double rates in the last 5 years, from 0.60 to 1.25 $\mathrm{cm}$ year $^{-1}$. This increment was attributed to enhanced human activities such as urbanization, deforestation, agriculture, road paving and dredging. The contribution of sedimentary organic matter varying from 4.2 to $41.7 \mathrm{~mol} \mathrm{C} \mathrm{m}^{-2}$ year $^{-1}$ in the last 100 years also presents a temporal increase (Wagener, 1995; Carreira et al., 2002).

The sedimentary changes bring a well-known response of the marine benthos, with variations in the abundance, richness and dominance of the species. As in other estuaries, the dominant biota of GB reflects the high spatial and temporal variability of the environment (Andrade et al., 2016; Suchy et al., 2016). However, it presents features very similar to the biota of sites under anthropogenic stress, making it difficult to separate each other (Hyland et al., 2005).

The current methods to detect anthropogenic stresses in communities is also used to trace natural stresses, which make particularly important to associate different methodologies for a wider conclusive response on the effects of pollutants on GB biota. Multi/interdisciplinary studies, such as "Sediment Quality Triads", and population dynamics are fundamental to understand the evolution of GB biota in a framework of environmental recovery.

Many environmental monitoring studies focus on macrofaunal diversity (e.g. Borja et al., 2000, 2003, 2004a, b; Muxika et al., 2005). However, benthic foraminifera, which have been applied since the early 1960s (Watkins, 1961; Schafer, 1973; Ellison et al., 1986; Alve, 1995; Yanko et al., 1998, 1999; Alve and Olsgardt, 1999), have recently reached a prominent role as bioindicators of environmental quality (Tomas et al., 2000, Debenay et al., 2001, Frontalini and Coccioni, 2008; Caruso et al., 2011; Schönfeld, 2012; Martins et al., 2013, 2015, 2016a, b; Dimiza et al., 2016a, b).

Their small size, high degree of adaptation, sensitivity to environmental variations and their high values of density and richness (Schönfeld, 2012) contribute to their use, particularly in environmental impact studies in coastal areas (Tomas et al., 2000, Debenay et al., 2001, Frontalini and Coccioni, 2008; Caruso et al., 2011; Schönfeld, 2012; Martins et al., 2013, 2015, 2016a, b; Dimiza et al., 2016a, b).

Variations in diversity and density are examples of how factors related to pollution, such as high concentrations of metals and organic matter, can affect these microorganisms (Boltovskoy, 1956; McCrone and Schafer, 1966; Seiglie, 1968; Alve, 1991; Casamajor and Debenay, 1995; Yanko et al., 1998, 1999; Samir, 2000; Vilela et al., 2004; Schönfeld, 2012). 
Several studies based on foraminifera (total of live and dead organisms) aiming to analyze the response of these organisms to environmental stress have been performed in GB (Vilela et al., 2004; Kfouri et al., 2005).

The study of Vilela et al. (2004) included samples collected in the Niterói harbor and close to Conceição and Jurujuba islands, places regarded as of intense naval activity and subjected to the discharge of high amount of pollutants. Low foraminiferal density and the dominance of Buliminella elegantissima, Ammonia tepida and Bolivina lowmani in fine grained sediments enriched in organic matter and metals contents were documented (Vilela et al., 2004). The first two species have been associated with high environmental stress conditions in several coastal ecosystems (e.g. Yanko et al., 1994, 1999; Alve, 1995; Culver and Buzas, 1995; Debenay et al., 2000; Van der Zwann, 2000).

Pereira et al. (2006) also associated the characteristics of benthic foraminiferal assemblages (total of living and dead specimens) to abiotic factors. Similarly, to Vilela et al. (2004), Pereira et al. (2006) reported that A. tepida and B. elegantissima were dominant species along with Bolivina striatula in the bay. They observed that both in winter and summer, sediments with high organic carbon content were mainly populated by $A$. tepida in the northern sector, while in the central areas of the bay, B. elegantissima and B. striatula were the most common species. This may be due the tolerance of $A$. tepida to low salinity and the opportunistic behavior of these species, as pointed out by Eichler et al. (1995) and Benhard and Sen Gupta (1999).

More recently, Donnici et al. (2012) studied a much larger sample network composed by 88 sedimentary samples in which foraminiferal assemblages (live plus dead specimens) were mostly dominated by $A$. tepida and B. elegantissima. These authors concluded that the northwest sector of GB was the most polluted, while the southeast part that has a direct connection to the sea was less affected by pollution.

Although these studies represent a considerable step towards the understanding of the foraminiferal faunas in GB, they all dealt with total foraminiferal assemblages. According to the "The FOBIMO (FOraminiferal BIoMOnitoring) initiative-Towards a standardized protocol for soft-bottom benthic foraminiferal monitoring studies" (Schönfeld et al., 2012), prepared by several researchers in foraminiferal ecology, the methodological approach for environmental studies evaluation would be exclusively based on living specimens.

\subsection{The main goals of this study}

This work aims to compare the similarity between living and dead benthic foraminiferal assemblages of the NE Sector of GB and to evaluate the factors that mostly contribute for the dissimilarity between both assemblages. This work also aims to search for bioindicators of the environmental impact and its applicability for environmental biomonitoring.

\section{Study area}

Guanabara Bay is located in Rio de Janeiro state, southeast of Brazil, between $22^{\circ} 40^{\prime} \mathrm{S}$ and $23^{\circ} 00^{\prime} \mathrm{S}$ of latitude and $43^{\circ} 00^{\prime} \mathrm{W}$ and $43^{\circ} 18^{\prime} \mathrm{W}$ longitude. The bay covers an area of $\sim 380 \mathrm{~km}^{2}$ and is connected to the Atlantic Ocean by a main channel that extends from the entrance to its inner part (Kjerfve et al., 1997; Figueiredo et al., 2014). The bay has a semi-circular format of $30 \mathrm{~km}$ and $28 \mathrm{~km}$ in the N-S and E$\mathrm{W}$ axes, respectively. The channel can be divided in two portions one from the bay entrance to the Rio-Niterói Bridge and the other from the bridge to the Governador and Paquetá islands (Quaresma et al., 2000). About $84 \%$ of the bay water is shallower than $10 \mathrm{~m}$ of depth but, in the region of the central channel, the bottom could reach more than 40 $m$ deep (Figueiredo et al., 2014).

The drainage basin of GB has an area of $4,080 \mathrm{~km}^{2}$ and is composed of 32 distinct fluvial sub-basins. Six rivers are responsible for $85 \%$ of fluvial input into the bay varying from 100 to $230 \mathrm{~m}^{3} \mathrm{~s}^{-1}$ per year (Carreira et al., 2002). Unfortunately, several forms of anthropogenic impacts have threatened its environmental conditions since the beginning of the European colonization in 1500 A.D (Vilela et al., 2014). Nowadays, the edge and surroundings of GB are heavily urbanized and the bay receives inputs of both industrial and domestic sewage, as well as residuals of agricultural crops (Kjerfve et al., 1997; Xavier de Brito et al., 2002). In spite of the huge load of pollutants and their potential impacts, the bay supports important regional fisheries (Jablonski et al., 2006) and still retains $40 \%$ of original mangrove forestry (Pires, 2010), half of which are relatively well preserved in environmental protection areas such as Guapimirim Protected Area (Soares-Gomes et al., 2010). Nowadays, GB is considered one of the most degraded coastal environments in Brazil (Kjerfve et al., 1997, Baptista Neto et al., 2000; Machado et al., 2004; Aguiar et al., 2011). Despite of these anthropogenic stresses, GB has a rich biodiversity in its waters, containing species of fish, cetaceans, mollusks, as well as species of benthic organisms 
such as diatoms (Soares-Gomes et al., 2016) and foraminifera (Clemente et al., 2015).

\section{Material and methods}

This work analyses the abundance and composition of dead assemblages of benthic foraminifera found in the surface sediment samples of nine stations collected in water depths between $\approx 2.5-5 \mathrm{~m}$, in the $\mathrm{NE}$ region of $\mathrm{GB}$ on 27.01.2016 (Fig. 1; Appendix 1). These samples are the same analyzed by Delavy et al. (2016) and Martins et al. (2016c). The analyzed samples correspond to the first centimeter of the sediment obtained in at least three independent deployments of a box-corer in each studied station (Schönfeld et al., 2012).
To identify the living and dead organisms a solution of ethanol (90\%) and Rose Bengal (2 g of Rose Bengal in 1000 $\mathrm{ml}$ alcohol) was added to the sediment for foraminiferal analyses during sampling. Samples were preserved with this solution for 16 days and along this time were gently shaken to entirely homogenize the mixture. Samples for sedimentological analysis were cool preserved.

The dead foraminiferal assemblages are compared in this work with selected results previously acquired and analyzed by Delavy et al. (2016) and Martins et al. (2016c), namely water physicochemical parameters, textural and geochemical results and living benthic (Rose Bengal stained) foraminifera. The methodology of analyses of these data is also described by these authors.

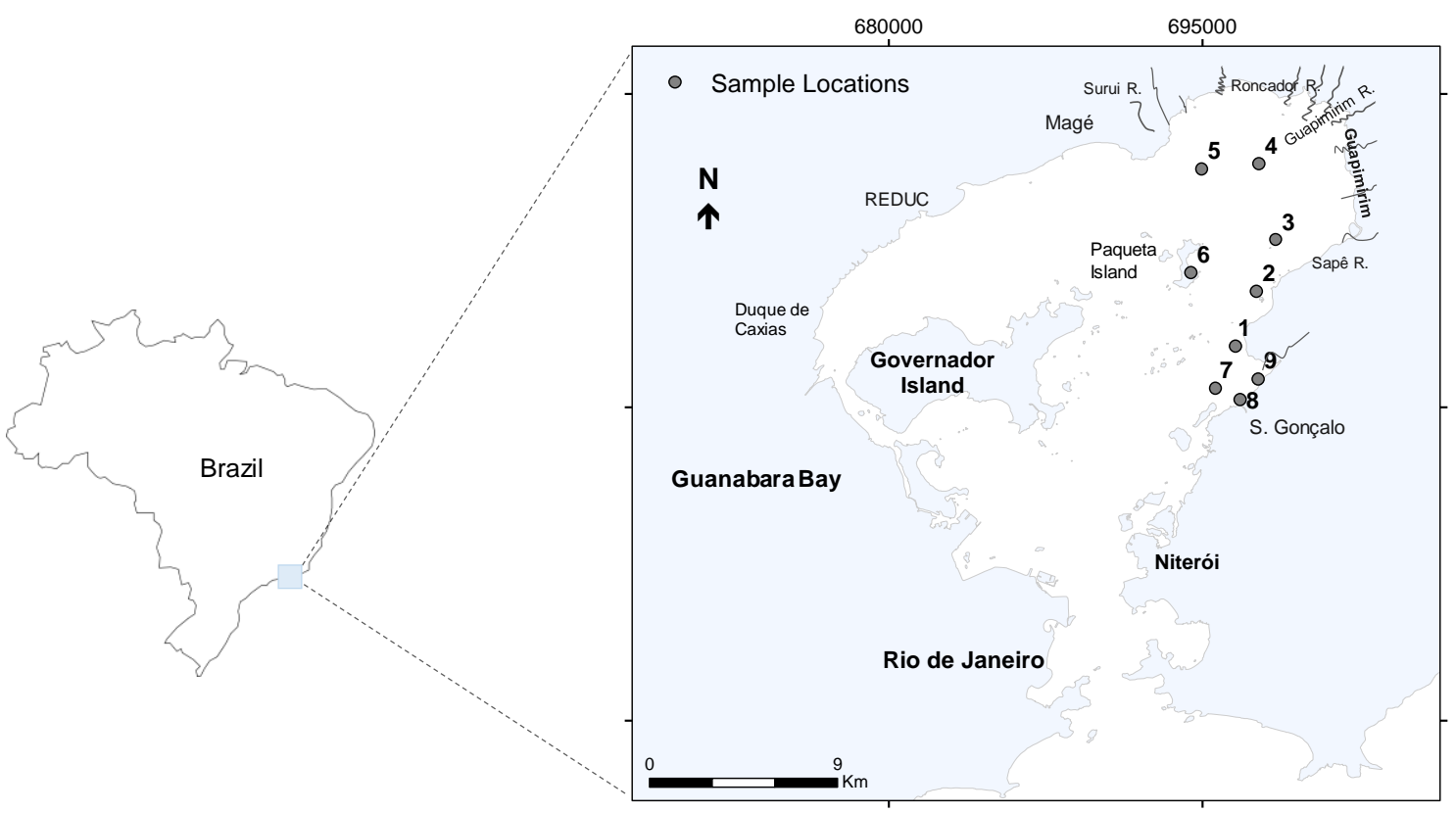

Fig. 1. Samples location in Guanabara Bay (Rio de Janeiro State, Brazil). Legend: REDUC-Duque de Caxias refinery; S. Gonçalo-São Gonçalo.

\subsection{Geochemical data}

Concentrations of $\mathrm{Cr}, \mathrm{Cu}, \mathrm{Pb}$ and $\mathrm{Zn}$ were analyzed by $\mathrm{X}$-Ray Fluorescence (XRF) technique with a Panalytical equipment, Axios model, in the Geosciences Department Laboratory of X-Ray Analysis of Universidade de Aveiro (Portugal) in fine fraction $(<63 \mu \mathrm{m})$ of each sample. The loss on ignition (LOI) was also determined using $5 \mathrm{~g}$ of sediment, at $1000^{\circ} \mathrm{C}$ for 16 consecutive hours in a muffle. The LOI evaluates the total amount of volatile substances in a sediment sample.
The enrichment factor for polluting metals were determined to evaluate the degree of contamination. The enrichment factor was calculated using the relation, EF = $[\mathrm{Cn} / \mathrm{Cref}] /[\mathrm{Bn} / \mathrm{Bref}]$ where $\mathrm{Cn}$ is the measured concentration of the element in sediment, Cref is the content of the examined element in the reference environment, $\mathrm{Bn}$ is content of the reference element in the examined environment and Bref is the background level of trace elements in mud sediment of Jurujuba (Baptista et al., 2000). Five contamination categories were recognized on the basis of the enrichment factors (Sutherland 2000). 
The Geo-accumulation index (Igeo) was also determined. The Igeo was calculated using the formula Igeo $=\log _{2}$ [Cn/1.5 Bn] where $\mathrm{Cn}$ is the measured concentration of the element in sediment, $\mathrm{Bn}$ is the geochemical background value from Background level of trace elements in mud sediment of Jurujuba (Baptista et al. 2000) and 1.5 is a constant. The Igeo consists of 7 grades or classes (Müller, 1981).

\subsection{Foraminiferal analysis}

The dead specimens found in splits of the following sediment fractions $63-150 \mu \mathrm{m}, 150-250 \mu \mathrm{m}, 250-500 \mu \mathrm{m}$ and $>500 \mu \mathrm{m}$ of each composite sample (were identified and counted using a light microscope in the Laboratory of Micropaleontology of Universidade do Estado do Rio de Janeiro (LMP-UERJ). The living foraminiferal specimens were also accounted in the same split of sediment fractions to compare with the abundance of dead benthic foraminifera. Whenever possible at least 300 specimens were counted and identified in each sediment fraction and in each station. The total abundance of living and dead specimens found in each sample, the sum of specimens per species identified in all the sedimentary fractions, which represent as a whole both assemblages in each station, are also compared in this work.

Foraminiferal density (FD), the number of living or dead specimens (stained) per gram of bulk sediment, was calculated in each analyzed sediment fraction $(63-150 \mu \mathrm{m}$, $150-250 \mu \mathrm{m}, 250-500 \mu \mathrm{m}$ and $>500 \mu \mathrm{m})$. As no foraminifera was found in the sediment fraction $>500 \mu \mathrm{m}$, FD per station was evaluated in sediment fraction $63-500 \mu \mathrm{m}$ per gram of bulk sediment.

Following the methodology established by Martins et al. (2016c), we define the dead foraminiferal assemblage (DFA) or living foraminiferal assemblage (LFA) as the dead and living specimens occurring in the sediment fraction 63-500 $\mu \mathrm{m}$, respectively. The dead and living specimens in the 63$150 \mu \mathrm{m}$ sedimentary fraction as foraminifera of the fine fraction (FFF) are defined as DFFF and LFFF, respectively; in the 150-250 $\mu \mathrm{m}$ sediment fraction as foraminifera of the medium fraction (FMF), dead (DFMF) and living (LFMF), respectively and; in the $250-500 \mu \mathrm{m}$ sedimentary fraction as foraminifera of coarse faction (FCF), dead (DFCF) and living (LFCF), respectively.

The percentage of each species in each sediment fraction and in the total assemblage (in sediment fraction 63-500 $\mu \mathrm{m}$ ), the richness of species (S), the Shannon index $\left(\mathrm{H}^{\prime}\right)$ and equitability or evenness (J') were calculated with Primer 6 software.

\subsection{Statistical Analysis}

Biotic data were statistically analyzed with R- and Qmode cluster analyses (CA) using "Wards' method" and "Euclidean Distances" to compare dead and living species distribution in each station and dead and living assemblages in each sediment fraction of each station. Station GB8 characterized by a too low number of foraminifera was not considered in CA. In the other stations, the number of foraminifera is $>300$ per sample. The sediment fractions with a number of dead and/or living foraminifera $<100$ were not also accounted in statistical analysis. Only the most frequent foraminiferal species (with a relative abundance $\geq 3 \%$ in at least three stations and at least five sediment fractions) were used in CA. Variables were logarithmically transformed $[\log (\mathrm{X}+1)]$ before analyses. The $\mathrm{CA}$ was carried out in Statistica 12.0 software. A Bray-Curtis similarity analysis was performed in PAST (Hammer et al., 2001) to determine the similarity of dead and living population.

\section{Results}

\subsection{Living and dead benthic foraminiferal assemblages in the 63 - 500 um sediment fraction}

Dead and living FD in the sediment 63-500 $\mu \mathrm{m}$ fraction ranged between 1 and $7558\left(\mathrm{n}^{\circ} / \mathrm{g}\right)$ and 1 and $3487\left(\mathrm{n}^{\circ} / \mathrm{g}\right)$, respectively (Figs. 2A and B; Appendices 2 and 3). Stations with the highest dead FD were GB5 and GB1 and living ones were GB5 and GB7. The lowest FD both for dead and living FD were found in stations GB8, GB9, GB4 and GB3. A total of 46 living and 44 dead benthic foraminiferal species has been recognized (Appendices 2 and 3), among which 30 were alive and 38 dead during the sampling event (Fig. 2C and D). The H' for the dead and living assemblages were $<1.63$ and $<1.75$, respectively (Appendices 2 and 3). The highest values of $\mathrm{H}^{\prime}$ for both dead and living assemblages were found in stations GB6 and GB7 (Fig. 2E and F). Low diversified living and dead assemblages of benthic foraminifera were found in the other stations. The J' for the dead and living assemblages were $<0.51$ and $<0.57$, respectively. The highest J' values were found in stations GB6, GB7 and GB9 both in dead and living assemblages (Fig. $2 \mathrm{G}$ and $\mathrm{H}$ ). In the other stations the J' values were commonly lower than 0.37 in both assemblages.

Eight species reached relative abundances $\geq 3 \%$ in the dead assemblages: A. tepida (52-96\%), Reophax nana (1-29\%), 
Cribroelphidium excavatum ( $<27 \%)$, Ammotium salsum $(<10 \%)$, B. elegantissima $(<10 \%)$, B. striatula $(<7 \%)$, Elphidium gerthi $(<4 \%)$, and Discorbis parkeri $(<4 \%)$.

The most abundant species in living assemblage were the same of the dead counterpart but with different percentages and include Bolivina compacta and Rosalina floridana. Percentage of agglutinated foraminifera is $<29 \%$ and $<18 \%$ in dead and living assemblages, respectively. Samples with the highest percentage of agglutinated foraminifera were the same in dead and living assemblages by decreasing order in GB3, GB9 and GB6. In general, the percentage of agglutinated foraminifera were higher in dead than in living assemblages, except in stations GB5 and GB7, where an inversed relationship was present. Miliolids were poorly represented with values $<3 \%$ both in dead and living foraminifera assemblages.

\subsection{Living and dead benthic foraminiferal assemblages in the 63- 150 um sediment fraction}

Living and dead FD were $<3229\left(\mathrm{n}^{\circ} / \mathrm{g}\right)$ and $<7102$ $\left(\mathrm{n}^{\circ} / \mathrm{g}\right)$, respectively (Fig. $3 \mathrm{~A}$ and B; Appendices 3 and 4). Stations with the highest dead and living FD were GB5, GB6 and GB1, whereas the lowest FD for both dead and living FD were found in stations GB8, GB9 and GB4. The S was $<21$ in living assemblage and $<20$ for dead assemblages of benthic foraminiferal species in 63-150 $\mu \mathrm{m}$ sediment fraction (Fig. 3C and D). The highest values of $\mathrm{S}$ were recognized in GB6 station both for dead and living assemblages. The H' for the dead and living assemblages were $<2.57$ and $<2.78$, respectively (Appendices 3 and 4). The highest values of $H^{\prime}$ were found in GB6 and GB7 stations (Fig. 3E and F) for both dead and living assemblages. The J'values for the dead and living assemblages were $<0.59$ and $<0.73$, respectively. The highest values of J' were also found in GB6 and GB7 (Fig. 3G and $\mathrm{H}$ ) for both assemblages. Six species reached relative abundances $\geq 3 \%$ in the dead assemblages that are A. tepida (52-89\%), B. elegantissima (>31\%), R. nana $(>31 \%)$, C. excavatum $(>6 \%), B$. striatula $(>11 \%)$ and Trochammina inflata $(>3 \%)$. The same species, though with a different relative abundance, dominated the living assemblages

\subsection{Living and dead assemblages in 63-500 $\mu \mathrm{m}$ sediment fraction}

The R-mode CA comparing the distribution of FD, H', J', S' and the most frequent species in both living and dead assemblages of benthic foraminifera (A. tepida, $A$. salsum, $C$. excavatum, G. praegeri, E. gerthi, D. parkeri, B. striatula, R. floridana, B. compacta, B. elegantissima and R. nana) in the 63-500 $\mu \mathrm{m}$ sediment fraction is presented in Figure 4. Results of CA evidence that the distribution pattern of these parameters is quite similar for both assemblages. Ammonia tepida is related to FD for both in dead and living assemblages, whereas the other species and parameters for both dead and living assemblages represent a different cluster (Fig. 4).

The species identified only in dead and living assemblages in 63-500 $\mu \mathrm{m}$ (Fig. 5A and B) and 63-150 $\mu \mathrm{m}$ (Fig. 5C and D) sediment fractions were reported in Figure 5. Some differences are highlighted from this comparison where some species only occur in the living assemblage or in the dead one in different stations. In the 63-500 $\mu \mathrm{m}$ sediment fraction, the dead assemblages included, in general, more exclusive species than the living ones: the highest difference was observed in the stations GB6 (15 species/taxa) and GB1 (8 species) and the lowest in GB4 and GB8 (with very small abundance of foraminifera). The difference in the other stations included 5 species.

\subsection{Dead and living assemblages in 63-150 um sediment fraction}

The 63-150 $\mu \mathrm{m}$ sediment fraction also commonly included more exclusive species in dead assemblages than in living ones. The highest difference in the dead assemblage was observed in the stations GB2 (7 species) and GB6 (6 species) and the lowest in GB4. Stations GB8 and GB9 station were devoid of both living and dead foraminifera. The difference in the other stations is of 5 species. The highest number of exclusive living assemblages in the $63-150 \mu \mathrm{m}$ sediment fraction was found in GB6. On the other hand, in GB5 station where a high FD (Fig. 3) was found, both assemblages presented the same species but in station GB4 where the FD is reduced the living assemblages exhibited two exclusive species.

\subsection{Results of $Q$-mode $C A$ comparing biotic data related to dead and living assemblages in different sediment fractions}

A Q-mode CA was performed on FD, H', J', S' and the most frequent species (the same used in Figure 4) on living and dead assemblages for the 63-150 $\mu \mathrm{m}$ (1), 150-250 $\mu \mathrm{m}$ (2) and 250-500 $\mu \mathrm{m}$ (3) sediment fractions (Fig. 6). This analysis was based on the stations and sediments fractions where more than 100 dead and 100 living specimens were identified. The station GB8 was excluded from this analysis. Results of CA separates four main groups of stations and shows that in most of the analyzed stations the living and dead assemblages in different sediment fractions belong to different groups of variables. The stations where the living and dead assemblages in 63-150 $\mu \mathrm{m}$ and 150-250 $\mu \mathrm{m}$ sediment fractions belong to the same group are GB6, GB3 and GB4 (but in this station the living assemblage in the smaller sediment fraction was not considered due the reduced number of specimens; Appendix 4). 

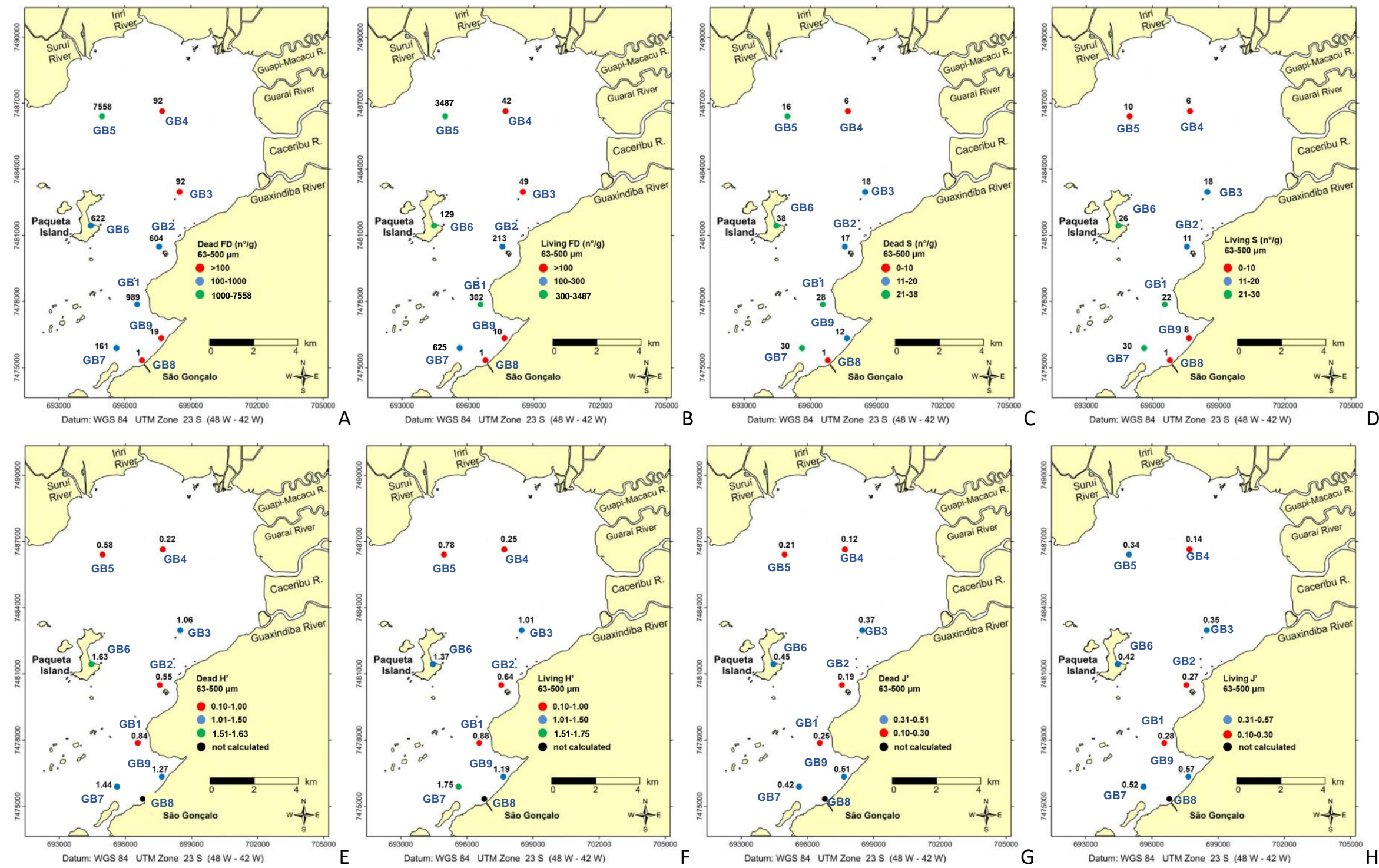

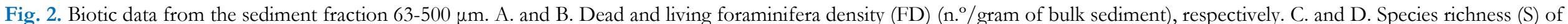

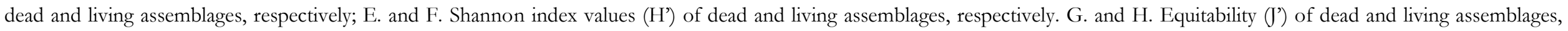
respectively. Legend: stations - GB1 to GB9 in blue letters; numbers in black bold values of FD, H' and J', in respective maps. Adapted from Delavy et al. (2016). 

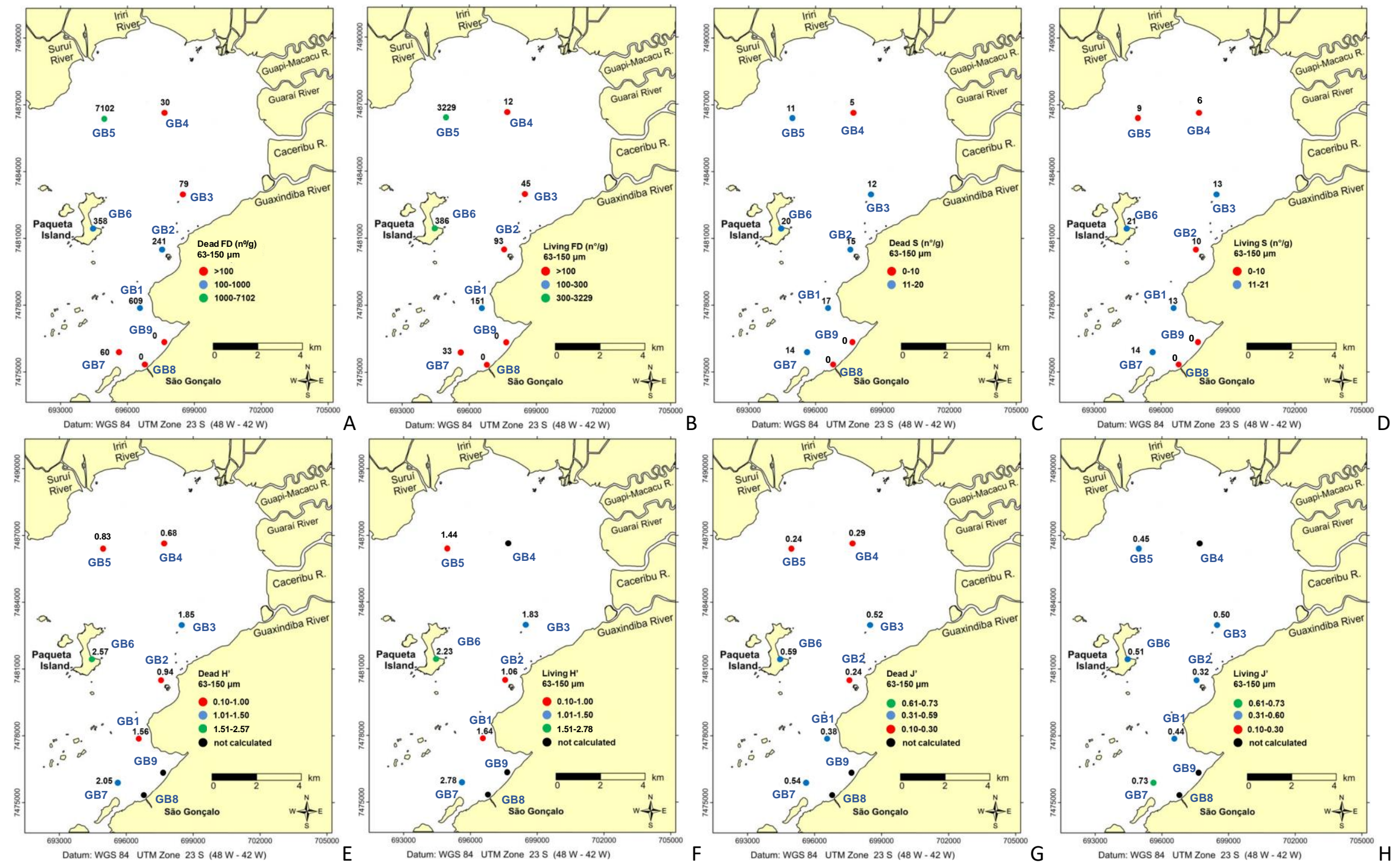

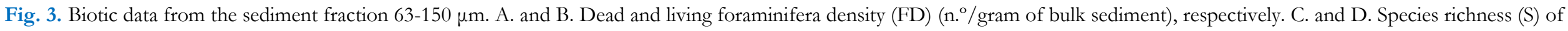

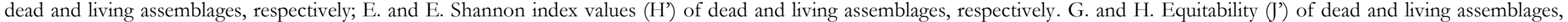
respectively. Legend: stationsGB1 to GB9 in blue letters; numbers in black bold values of FD, H' and J', in respective maps. Adapted from Delavy et al. (2016). 
The most abundant species in living assemblage were the same of the dead counterpart but with different percentages and include Bolivina compacta and Rosalina floridana. Percentage of agglutinated foraminifera is $<29 \%$ and $<18 \%$ in dead and living assemblages, respectively. Samples with the highest percentage of agglutinated foraminifera were the same in dead and living assemblages by decreasing order in GB3, GB9 and GB6. In general, the percentage of agglutinated foraminifera was higher in dead than in living assemblages, except in stations GB5 and GB7, where an inversed relationship was present. Miliolids were poorly represented with values $<3 \%$ both in dead and living foraminifera assemblages.

\subsection{Living and dead benthic foraminiferal assemblages in the 63- 150 um sediment fraction}

Living and dead FD were $<3229\left(\mathrm{n}^{\circ} / \mathrm{g}\right)$ and $<7102$ $\left(\mathrm{n}^{\circ} / \mathrm{g}\right)$, respectively (Fig. $3 \mathrm{~A}$ and B; Appendices 3 and 4). Stations with the highest dead and living FD were GB5, GB6 and GB1, whereas the lowest FD for both dead and living FD were found in stations GB8, GB9 and GB4. The $\mathrm{S}$ was $<21$ in living assemblage and $<20$ for dead assemblages of benthic foraminiferal species in 63-150 $\mu$ m sediment fraction (Fig. 3C and D). The highest values of $\mathrm{S}$ were recognized in GB6 station both for dead and living assemblages. The H' for the dead and living assemblages were $<2.57$ and $<2.78$, respectively (Appendices 3 and 4). The highest values of $\mathrm{H}^{\prime}$ were found in GB6 and GB7 stations (Fig. 3E and F) for both dead and living assemblages. The J' values for the dead and living assemblages were $<0.59$ and $<0.73$, respectively. The highest values of J' were also found in GB6 and GB7 (Fig. 3G and $\mathrm{H}$ ) for both assemblages.

Six species reached relative abundances $\geq 3 \%$ in the dead assemblages that are $A$. tepida (52-89\%), B. elegantissima $(>31 \%)$, R. nana $(>31 \%)$, C. excavatum $(>6 \%)$, B. striatula $(>11 \%)$ and Trochammina inflata $(>3 \%)$. The same species, though with a different relative abundance, dominated the living assemblages

\subsection{Living and dead assemblages in 63-500 um sediment fraction}

The R-mode CA comparing the distribution of FD, H', J', S' and the most frequent species in both living and dead assemblages of benthic foraminifera (A. tepida, A. salsum, $C$. excavatum, G. praegeri, E. gerthi, D. parkeri, B. striatula, R. floridana, B. compacta, B. elegantissima and R. nana) in the 63-500 $\mu \mathrm{m}$ sediment fraction is presented in Figure 4. Results of CA evidence that the distribution pattern of these parameters is quite similar for both assemblages. Ammonia tepida is related to FD for both in dead and living assemblages, whereas the other species and parameters for both dead and living assemblages represent a different cluster (Fig. 4).

The species identified only in dead and living assemblages in $63-500 \mu \mathrm{m}$ (Fig. 5A and B) and 63-150 $\mu \mathrm{m}$ (Fig. 5C and D) sediment fractions were reported in Figure 5. Some differences are highlighted from this comparison where some species only occur in the living assemblage or in the dead one in different stations. In the 63-500 $\mu \mathrm{m}$ sediment fraction, the dead assemblages included, in general, more exclusive species than the living ones: the highest difference was observed in the stations GB6 (15 species/taxa) and GB1 (8 species) and the lowest in GB4 and GB8 (with very small abundance of foraminifera). The difference in the other stations included 5 species.

\subsection{Dead and living assemblages in 63-150 um sediment fraction}

The 63-150 $\mu \mathrm{m}$ sediment fraction also commonly included more exclusive species in dead assemblages than in living ones. The highest difference in the dead assemblage was observed in the stations GB2 (7 species) and GB6 (6 species) and the lowest in GB4. Stations GB8 and GB9 were devoid of both living and dead foraminifera. The difference in the other stations is of 5 species. The highest number of exclusive living assemblages in the 63$150 \mu \mathrm{m}$ sediment fraction was found in GB6. On the other hand, in GB5 station where a high FD (Fig. 3) was found, both assemblages presented the same species but in station GB4 where the FD is reduced the living assemblages exhibited two exclusive species.

\subsection{Results of Q-mode CA comparing biotic data related to dead and living assemblages in different sediment fractions}

A Q-mode CA was performed on FD, H', J', S' and the most frequent species (the same used in Fig. 4) on living and dead assemblages for the 63-150 $\mu \mathrm{m}$ (1), 150-250 $\mu \mathrm{m}$ (2) and 250-500 $\mu \mathrm{m}$ (3) sediment fractions (Fig. 6). This analysis was based on the stations and sediments fractions where more than 100 dead and 100 living specimens were identified. The station GB8 was excluded from this analysis.

Results of CA separates four main groups of stations and shows that in most of the analyzed stations the living and dead assemblages in different sediment fractions belong to different groups of variables. The stations where the living and dead assemblages in 63-150 $\mu \mathrm{m}$ and 150-250 $\mu \mathrm{m}$ sediment fractions belong to the same group are GB6, GB3 and GB4 (but in this station the living assemblage in the smaller sediment fraction was not considered due the reduced number of specimens; Appendix 4). 


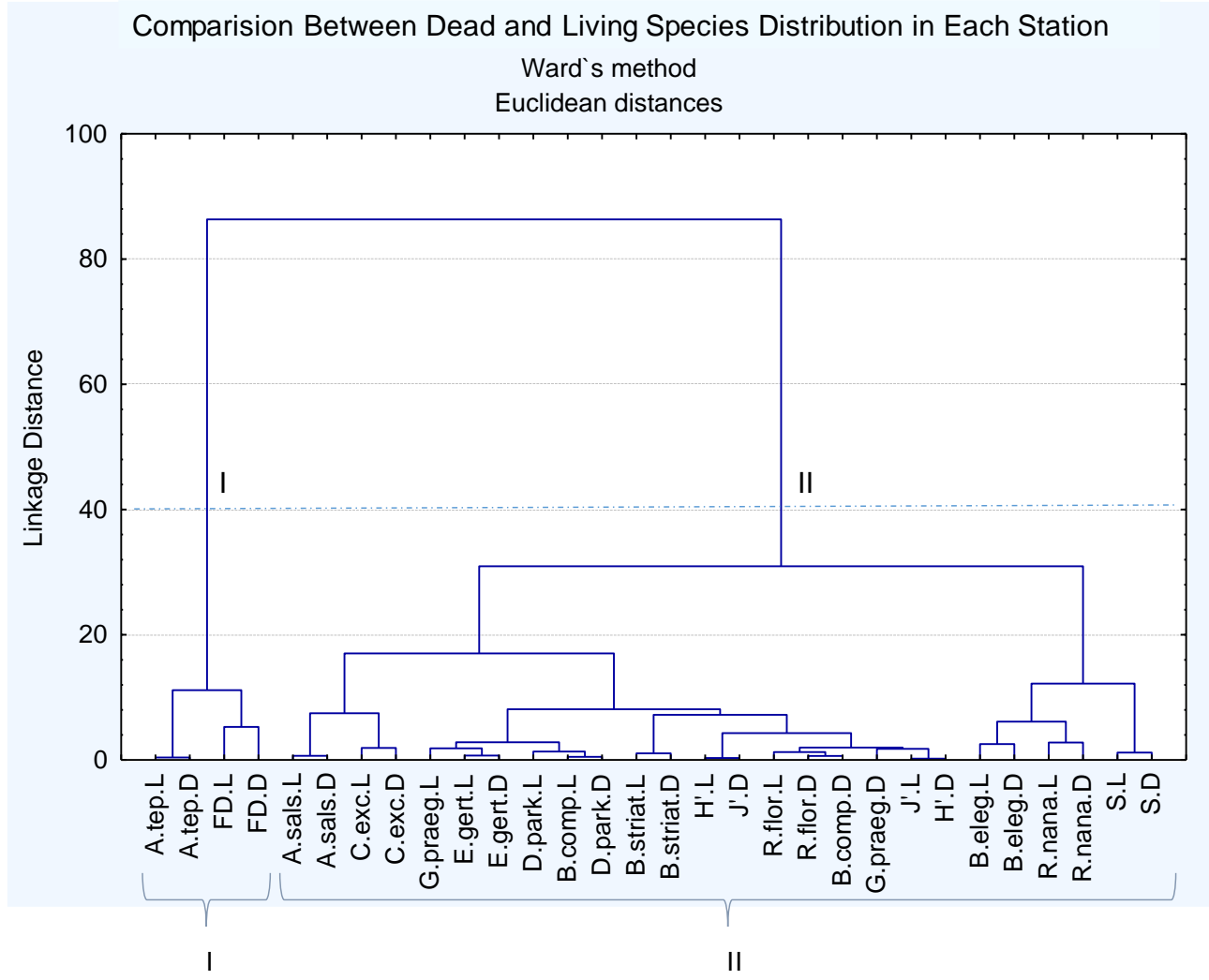

Fig. 4. Cluster analysis comparing the distribution of FD, H', J', S and the most frequent species in dead (D) and living (L) assemblages of 63-500 $\mu \mathrm{m}$ sediment fraction in the studied stations. Legend: A.tep - Ammonia tepida; A.sals - Ammotium salsum; C.exc - Cribroelphidium excavatum; G.praeg - Gavelinopsis praegeri; E.gert - Elphidium gerthi; D.park - Discorbis parkeri; B.striat - Bolivina striatula; R.flor - Rosalina floridana; B.comp - Bolivina compacta; B.eleg - Buliminella elegantissima; R.nana - Reophax nana.

\subsection{Results of Bray Curtis similarity between the dead and living

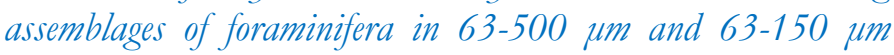 sediment fractions}

The results of the Bray Curtis similarity between the dead and living foraminiferal assemblages in the $63-500 \mu \mathrm{m}$ and $63-150 \mu \mathrm{m}$ sediment fractions are presented in Figure $7 \mathrm{~A}$ and $\mathrm{B}$, respectively. The Bray-Curtis similarity between both assemblages in sediment fractions: i) $63-500 \mu \mathrm{m}$ is higher than $70 \%$ in GB2, GB6, GB7 and GB9 stations and lower than 50\% in GB1 and GB4 stations and; ii) 63-150 $\mu \mathrm{m}$ is higher than $70 \%$ in GB6, GB7 and GB3 stations and lower than 50\% in GB1, GB2 and GB4.

\subsection{Abiotic variables}

Salinities varied from 12.1-35.9, $\mathrm{pH}$ from 7.7 to 8.5, oxygen content ranged from $5.4-9.7 \mathrm{mg} / \mathrm{l}$ and the mean temperature was about $30^{\circ} \mathrm{C}$ (Appendix 1). The bottom sediments, for most of the sites, were composed by mud or sandy mud sediments with fine fraction content ranging from $27-95 \%$ (mean $73 \%$ ) and sediment mean grain size from 17-125 $\mu \mathrm{m}$ (mean $42 \mu \mathrm{m}$ ) (Appendix 1).

Total organic carbon content and LOI varied between 1.5-5.8\% (mean 3.7\%) and 15.5-25.4\% (mean 19.68\%), respectively. The sedimentary content in minor elements such as $\mathrm{Cr}\left(53-86 \mathrm{mg} \mathrm{kg}^{-1}\right.$, mean $\left.66 \mathrm{mg} \mathrm{kg}^{-1}\right), \mathrm{Cu}(26-63 \mathrm{mg}$ $\mathrm{kg}^{-1}$; mean $\left.40 \mathrm{mg} \mathrm{kg}^{-1}\right), \mathrm{Pb}$ (44-71 $\mathrm{mg} \mathrm{kg}^{-1}$; mean $53 \mathrm{mg} \mathrm{kg}^{-1}$ ) and $\mathrm{Zn}\left(100-250 \mathrm{mg} \mathrm{kg}^{-1}\right.$; mean $\left.161 \mathrm{mg} \mathrm{kg}^{-1}\right)$ increased in some areas (Fig. 8 C-D) such as close to São Gonçalo region. At the Paqueta Island, a slight increase of $\mathrm{Pb}$ and $\mathrm{Cu}$ was also recorded. The results of the $\mathrm{EF}$ for $\mathrm{Cr}, \mathrm{Cu}, \mathrm{Pb}$ and $\mathrm{Zn}$ are presented in Table 1 and of the Igeo for the same chemical elements in Table 2. 


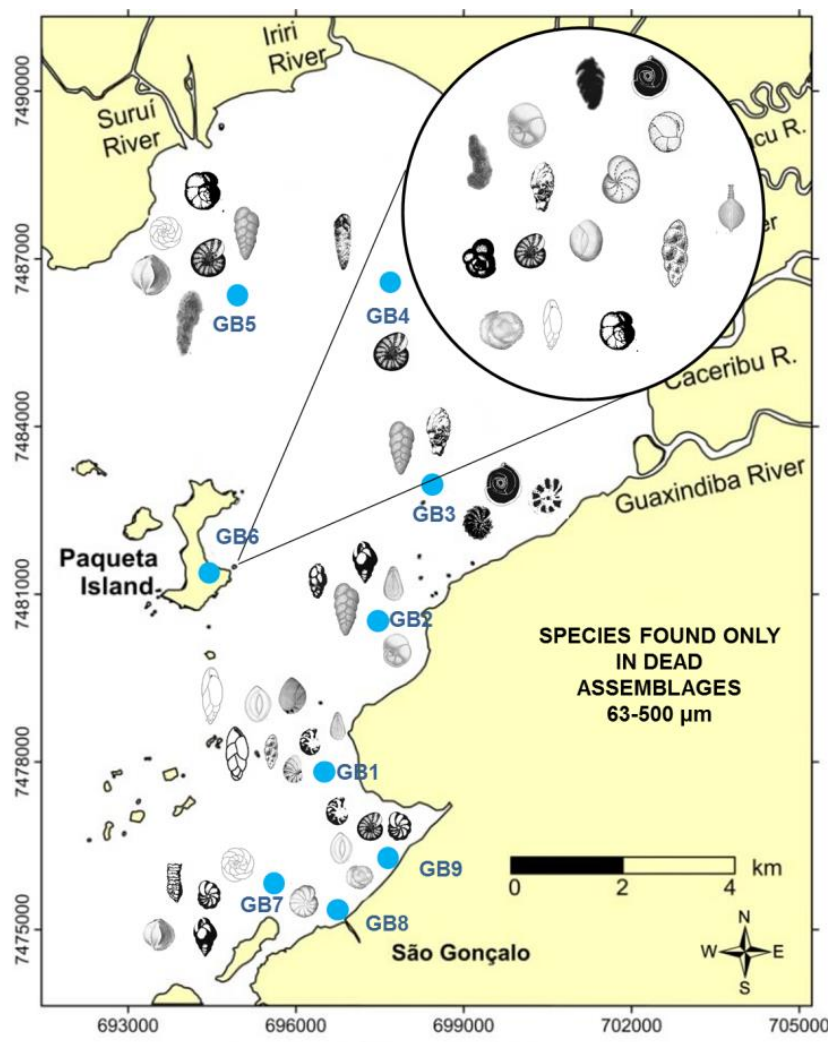

Datum: WGS 84 UTM Zone 23 S (48 W - 42 W)

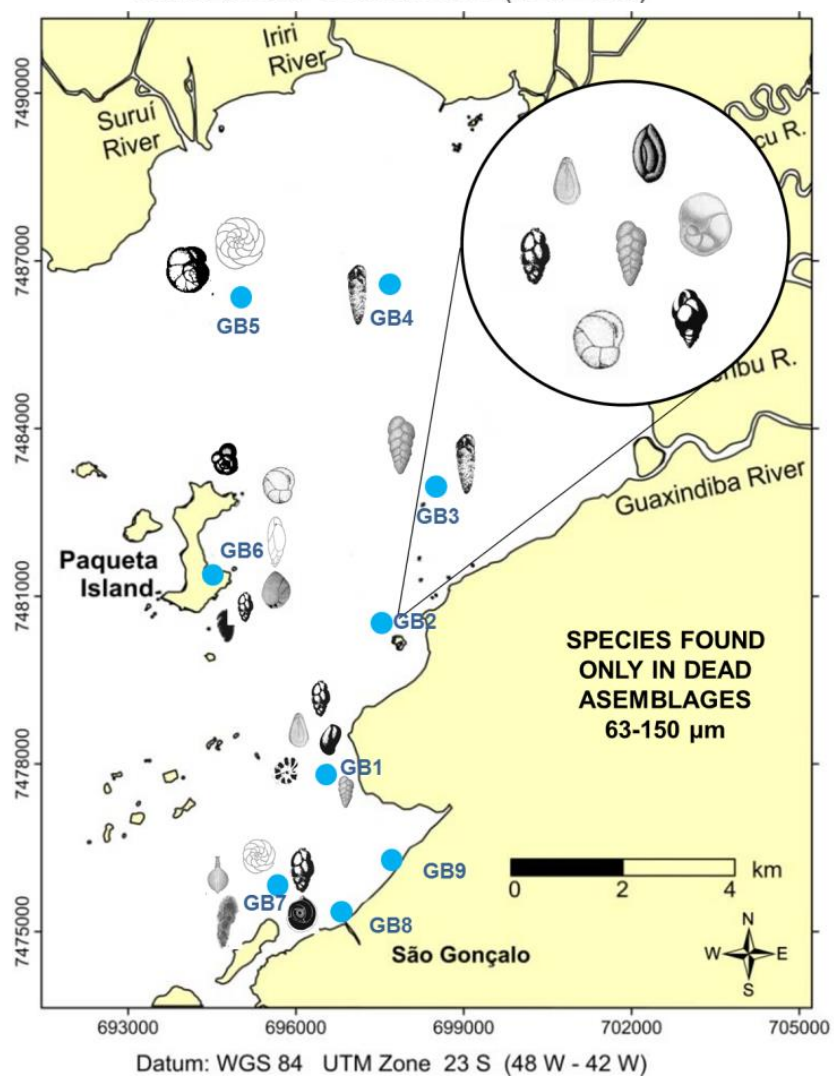

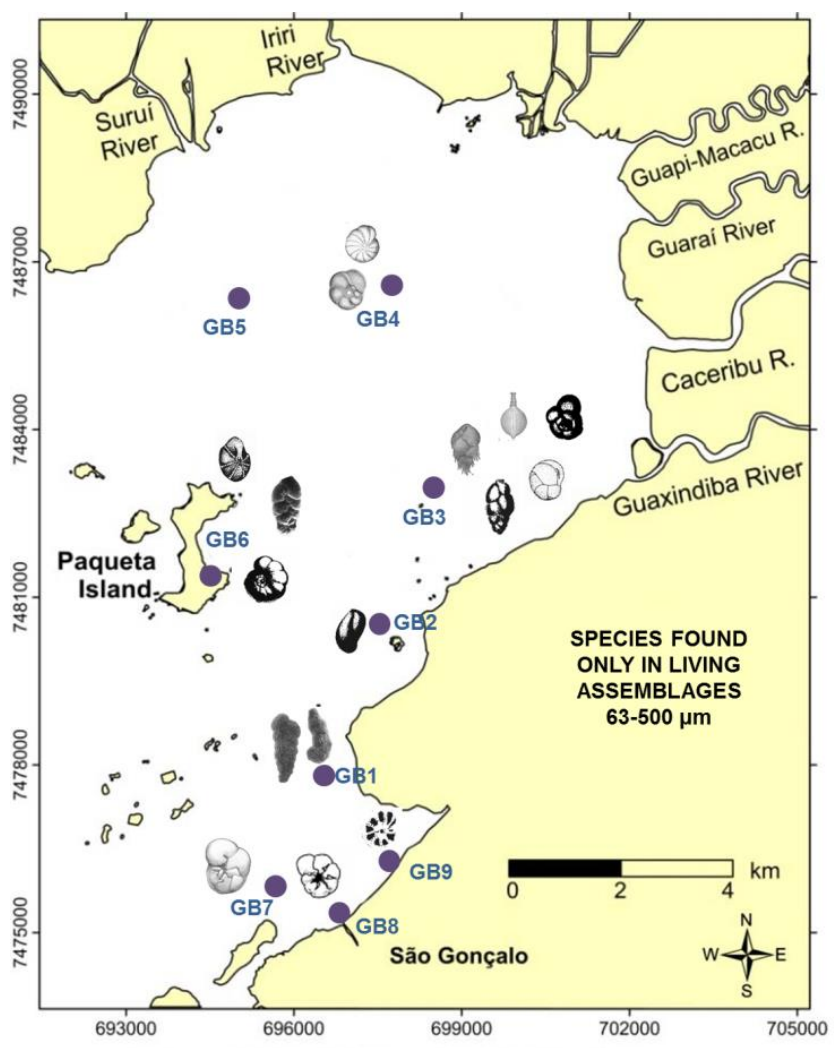

A

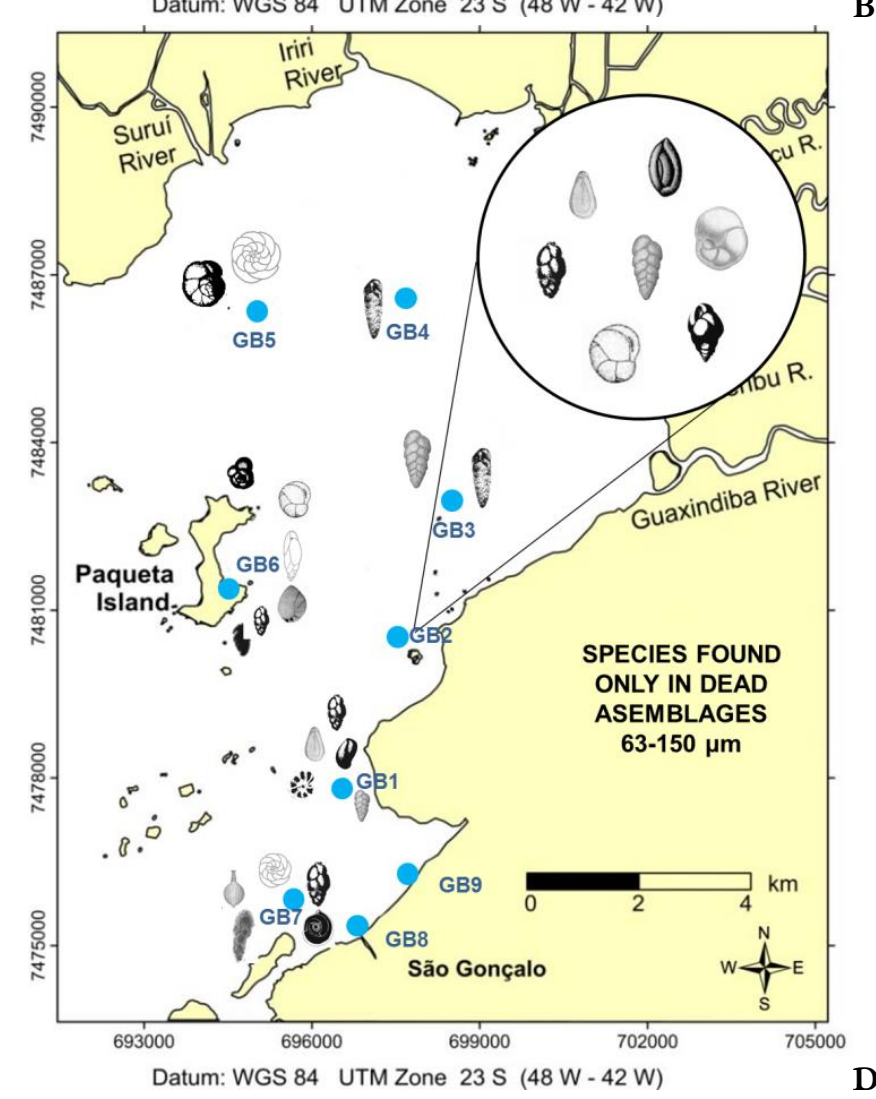

Fig. 5. Species found only in dead and living assemblages in sediment fractions 63-500 $\mu \mathrm{m}$ and 63-150 $\mu \mathrm{m}$. Adapted from Delavy et al. (2016). Legend: stations GB1 to GB9 in blue letters. Legend: 


\begin{tabular}{|c|c|c|c|}
\hline Ammonia parkinsoniana & Elphidium williamsoni & (0) Ophthalmidium balkwilli & 8 Trochammina inflata \\
\hline Ammotium salsum & (1) Fissurina lucida & Pseudoclavulina curta & 8 Trochulina dimidiatus \\
\hline Ammonia tepida & (8) Fursenkoina conspiqua & (1) Quinqueloculina laevigata & \\
\hline Bolivina compacta & (8) Fursenkoina pontoni & (1) Quinqueloculina lamarckiana & \\
\hline Bolivina lowmani & Gavelinopsis praegeri & Quinqueloculina poeyana & \\
\hline Bolivina striatula & Globocassidulina crassa & Quinqueloculina seminula & \\
\hline Bulimina aculeata & (1) Haplophragmoides wilberti & Reophaxcurtus & \\
\hline Bulimina gibba & Hopkinsina pacifica & Reophaxnana & \\
\hline Cribroelphidium albiumbilicatum & Lagena striata & Rosalina globularis & \\
\hline Cribroelphidium excavatum & Lepidodeuterammina ochracea & (8) Rosalina bradyi & \\
\hline Cribroelphidium poeyanum & Miliolids (partially dissolved) & Sagrina primitiva & \\
\hline Discorbis parkeri & Miliolinella lutea & Siphonina reticulata & \\
\hline Elphidium gerthi & Neoconorbina terquemi & Spirobolivina curta & \\
\hline Elphidium gunteri & की. Nonionella atlantica & Stainforthia fusiformis & \\
\hline Elphidium incertum & (2) Nonionella opima & Textularia earlandi & \\
\hline
\end{tabular}


According to the EF values presented in Table 1, Cu, $\mathrm{Zn}$ and $\mathrm{Pb}$ show depletion to minimal enrichment of these elements in most of the studied stations. A moderate enrichment of $\mathrm{Cu}$ and $\mathrm{Zn}$ was registered in front of São Gonçalo. All elements present maximal enrichment in front of São Gonçalo. The results of the Igeo indicate that the northern sector of GB shows moderately polluted surface sediment in most of the analyzed stations. The sediments were moderately polluted in $\mathrm{Cu}, \mathrm{Zn}$ and $\mathrm{Pb}$ in front of São Gonçalo.

Tab. 1. Enrichment factors for $\mathrm{Cr}, \mathrm{Cu}, \mathrm{Zn}$ and $\mathrm{Pb}$. Sutherland classification for the enrichment factors (Sutherland 2000): $<2$ Depletion to minimal enrichment; 2-5 - Moderate enrichment; 520 - Significant enrichment; 20-40 - Very high enrichment; $>40$ Extremely high enrichment.

\begin{tabular}{ccccc}
\hline EF & $\mathbf{C r}$ & $\mathbf{C u}$ & $\mathbf{Z n}$ & $\mathbf{P b}$ \\
\hline GB1 & 0.85 & 2.42 & 1.46 & 1.02 \\
\hline GB2 & 0.77 & 1.49 & 1.23 & 0.93 \\
\hline GB3 & 0.62 & 1.49 & 0.77 & 0.96 \\
\hline GB4 & 0.49 & 1.09 & 0.85 & 0.71 \\
\hline GB5 & 0.81 & 1.97 & 1.32 & 1.00 \\
\hline GB7 & 0.89 & 1.89 & 1.33 & 1.07 \\
\hline GB6 & 0.88 & 3.12 & 1.44 & 1.48 \\
\hline GB8 & 1.05 & 3.48 & 2.12 & 1.44 \\
\hline GB9 & 0.73 & 2.40 & 1.48 & 0.89 \\
\hline
\end{tabular}

\subsection{Comparison of Bray Curtis similarity between the dead and living foraminiferal assemblages and abiotic variables}

In the $63-500 \mu \mathrm{m}$ sediment fraction, the stations (GB2, GB6, GB7 and GB9) with the highest Bray-Curtis similarity (Fig. 7A) are characterized by higher mean values of salinity, oxygen, $\mathrm{pH}, \mathrm{Cr}, \mathrm{Cu}, \mathrm{Pb}$ and $\mathrm{Zn}$ and sediment mean grain size and lower mean values of fines, TOC, and LOI (Table 3). The stations (GB1 and GB4) that presented the lowest values of Bray-Curtis similarity (Fig. 7A) were instead characterized by an opposite trend for these variables. In 63-150 $\mu \mathrm{m}$ sediment fraction, the stations with highest (GB6, GB7 and GB3) and lowest (GB1, GB2 and GB4) Bray-Curtis similarity (Fig. 7B) are characterized by the same general characteristics observed for the 63-500 $\mu \mathrm{m}$ sediment fraction (Table 3). The only exception is represented by $\mathrm{Zn}$ that slightly higher concentrations are associated with stations with smaller Bray-Curtis similarity than in the other group.
Tab. 2. The results of the Igeo for $\mathrm{Cr}, \mathrm{Cu}, \mathrm{Zn}$ and $\mathrm{Pb}$. Müller classification for the Igeo (Müller, 1981): $\leq 0$ - Unpolluted; 0-1 From unpolluted to moderately polluted; 1-2 - Moderately polluted; 2-3 - From moderately to strongly polluted; 3-4 - Strongly polluted; $4-5$ - From strongly to extremely polluted; $>5$ - Extremely polluted

\begin{tabular}{ccccc}
\hline Igeo & $\mathbf{C r}$ & $\mathbf{C u}$ & $\mathbf{Z n}$ & $\mathbf{P b}$ \\
\hline GB1 & 0.19 & 1.69 & 0.96 & 0.45 \\
\hline GB2 & 0.00 & 0.96 & 0.68 & 0.28 \\
\hline GB3 & -0.11 & 1.15 & 0.19 & 0.51 \\
\hline GB4 & -0.21 & 0.93 & 0.57 & 0.30 \\
\hline GB5 & 0.17 & 1.45 & 0.87 & 0.47 \\
\hline GB7 & 0.29 & 1.38 & 0.87 & 0.56 \\
\hline GB6 & 0.07 & 1.89 & 0.78 & 0.82 \\
\hline GB8 & 0.50 & 2.23 & 1.51 & 0.95 \\
\hline GB9 & 0.09 & 1.81 & 1.12 & 0.38 \\
\hline
\end{tabular}

\section{Discussion}

\subsection{Characteristics of the living and dead total foraminiferal assemblages (TFA)}

The highest FD for both dead (DFA) and living (LDA) foraminiferal assemblages in the 63-500 $\mu \mathrm{m}$ sediment fraction are found at station GB5 that is an internal zone of Guanabara Bay where the highest values of salinity and oxygen content were also recorded. These results indicate that this station is located in the area with good water quality as pointed out by Paranhos and Andrade (2012) due to the turning of the tidal currents (Filippo and Figueired Jr, 2012). In this station, the sediments have relatively low concentrations of metals but display high organic matter content as marked by the high TOC content and LOI values (Appendix 1). As observed by Martins et al. (2016c), in this area the organic matter is in oxic state and might be marine in origin. The living assemblages of this area are largely dominated by $A$. tepida with small percentages of bolivinids and buliminids such as B. elegantissima, B. striatula, B. lowmani, B. aculeata, B. gibba, B. marginata, as well as C. excavatum, a quite common species in GB (Vilela et al., 2004, 2007, 2011, 2014; Donnici et al., 2012; Clemente et al., 2015). The presence of bolivinids and buliminids is also indicative of oceanic influence through tidal currents.

The FD of DFA is two to five times higher than the LFA, except in GB7, where FD of LFA is higher. These results indicate that the DFA corresponds to the accumulation of tests belonging to several generations of living communities 
in each studied place or to the deposition of allochthonous tests carried by the currents from other places. The predominance of living organisms at the station GB7 might suggest removal of sediments and/or loss of tests followed by a favorable event of reproduction of the species and repopulation at this area.

Foraminiferal diversity is low in the northeast area of GB as indicated by the species richness and Shannon index values. These values are however similar to those reported in previous studies such as Clemente et al. (2015) and relatively lower when compared with other transitional ecosystems (Martins et al, 2015, 2016a, b; Laut et al., 2016). The most frequent species in the studied stations are similar both in the dead and living assemblages and have been already reported in previous studies (Vilela et al., 2004, 2007, 2011, 2014; Donnici et al., 2012; Clemente et al., 2015). These taxa include A. tepida, C. excavatum (as Elphidium excavatum), B. elegantissima and B. striatula. The general distribution pattern of the main benthic foraminiferal species ( $A$. tepida, $A$. salsum, C. excavatum, G. praegeri, E. gerthi, D. parkeri, B. striatula, R. floridana, B. compacta, B. elegantissima and R. nana) is quite similar both in LFA and DFA as evidenced by the results of the R-mode cluster analysis (Fig. 4).

Ammonia tepida is the species that contribute the most for FD. Diversity and equitability both in LFA and DFA are mainly related to other species (A. salsum, $C$. excavatum, $G$. praegeri, E. gerthi, D. parkeri, B. striatula, R. floridana, B. compacta, B. elegantissima and $R$. nana). The $H^{\prime}$ values $(<1.63$ and $<1.75$ in DFA and LFA, respectively) are typical of a euryhaline ecosystem (Murray, 1991, 2006), since salinity is one of the factors that most influence foraminiferal diversity in the environment (Boltovskoy et al., 1980; Poag, 2015).

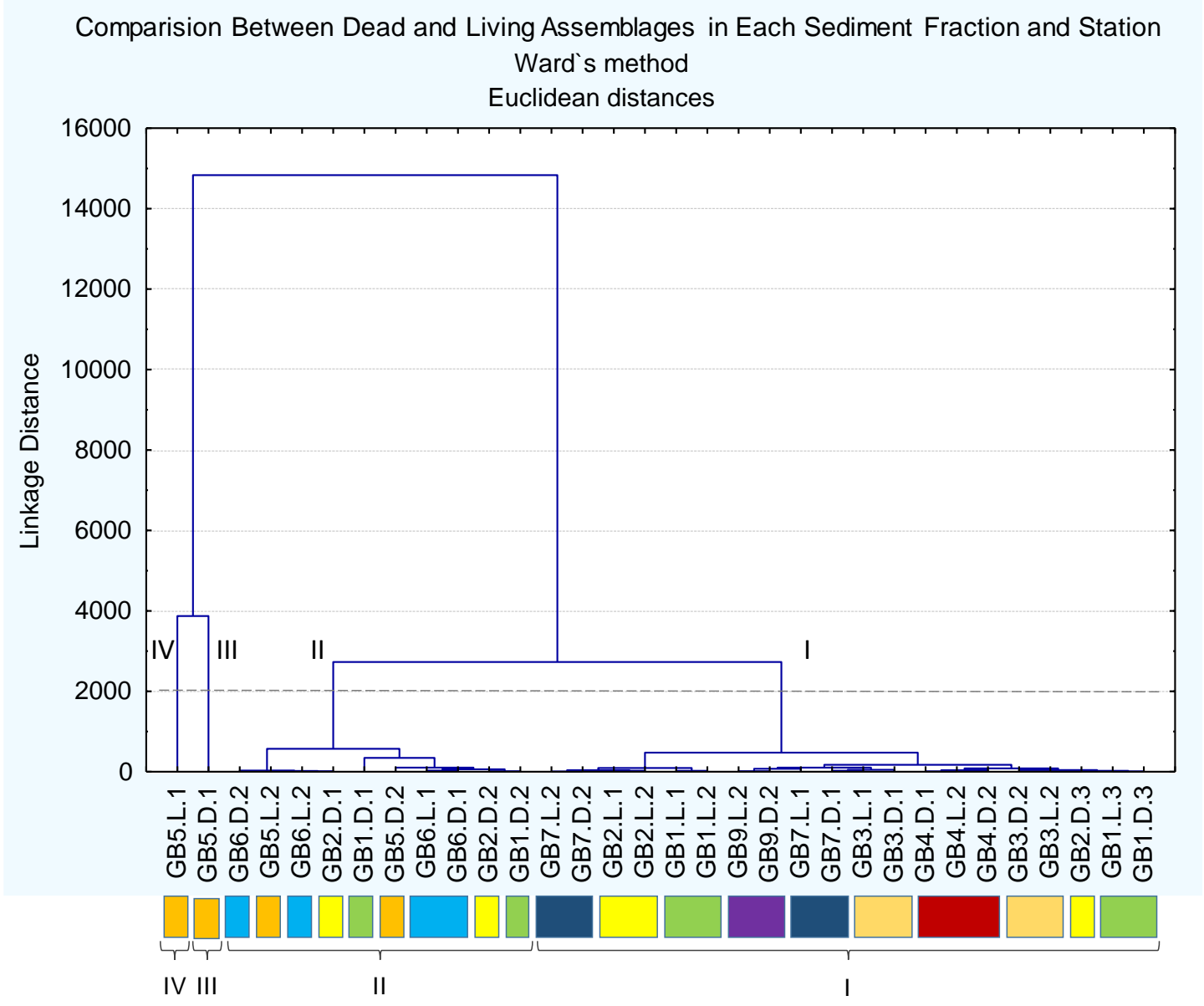

Fig. 6. Cluster analysis comparing the studied stations (GB1 to GB9) based on FD, H', J', S' and the most frequent species (the same used in Fig. 4) from the living (L) and dead (D) assemblages in the following sediment fractions: $1-63-150 \mu \mathrm{m} ; 2-150-250 \mu \mathrm{m}$ and 3 $-250-500 \mu \mathrm{m}$. Recognized two main groups of stations. Each station is signed with a rectangle with different color, in order to facilitate the analysis of these results. 
Tab. 3. Mean values for selected abiotic variables for the station groups with highest and lowest Bray-Curtis (B-C) similarity in 63-500 $\mu \mathrm{m}$ and 63-150 $\mu \mathrm{m}$ sediment fractions. Legend: SMGS - sediment mean grain size; LOI - loss on ignition.

\begin{tabular}{|c|c|c|c|c|c|}
\hline \multirow{2}{*}{\multicolumn{2}{|c|}{\begin{tabular}{l}
\multicolumn{1}{c}{ Sediment } \\
Fractions \\
Mean Values for \\
Variables
\end{tabular}}} & \multicolumn{2}{|c|}{$63-500 \mu \mathrm{m}$} & \multicolumn{2}{|c|}{ 63-150 $\mu \mathrm{m}$} \\
\hline & & $\begin{array}{c}\text { Highest B-C } \\
\text { Similarity }\end{array}$ & $\begin{array}{c}\text { Lowest B-C } \\
\text { Similarity }\end{array}$ & $\begin{array}{c}\text { Highest B-C } \\
\text { Similarity }\end{array}$ & $\begin{array}{c}\text { Lowest B-C } \\
\text { Similarity }\end{array}$ \\
\hline Salinity & & 29.9 & 16.9 & 26.3 & 18.3 \\
\hline $\mathrm{pH}$ & & 8.4 & 8.3 & 8.4 & 8.3 \\
\hline $\mathrm{O}_{2}$ & $\mathrm{mg} \mathrm{l}^{-1}$ & 7.3 & 6.5 & 6.8 & 6.4 \\
\hline Fines & $\%$ & 67.3 & 92.3 & 61.1 & 93.0 \\
\hline SMGS & $\mu \mathrm{m}$ & 47.7 & 17.6 & 57.0 & 17.4 \\
\hline TOC & $\%$ & 3.3 & 4.2 & 3.1 & 4.3 \\
\hline $\mathrm{Cr}$ & $\mathrm{mg} \mathrm{kg}^{-1}$ & 65.9 & 60.8 & 64.8 & 60.8 \\
\hline $\mathrm{Cu}$ & $\mathrm{mg} \mathrm{kg}^{-1}$ & 39.7 & 34.7 & 38.4 & 31.8 \\
\hline $\mathrm{Pb}$ & $\mathrm{mg} \mathrm{kg}^{-1}$ & 52.6 & 47.6 & 56.9 & 46.5 \\
\hline $\mathrm{Zn}$ & $\mathrm{mg} \mathrm{kg}^{-1}$ & 160.0 & 150.0 & 136.7 & 146.7 \\
\hline LOI & $\%$ & 18.4 & 20.4 & 18.9 & 21.2 \\
\hline
\end{tabular}

Unlike the FD, the Shannon index and equitability are higher in the LFA than the DFA except in GB6 (Appendices 2 and 3). These results might indicate a loss of diversity in the DFA probably by differential dissolution of tests in the most impacted areas by organic matter or by remobilization of the tests. Dissolution seems to affect for instance the miliolids that are in general poorly preserved in the dead assemblage making impossible the identification of some specimens at GB6 station located in the Paquetá Island harbor. Effects of dissolution were also observed in tests of living specimens of miliolids and of other species, mostly in the stations located near the NE rivers mouths. The DFA includes more exclusive species than the LFA one (Fig. 5). These results may indicate deposition of allochthonous materials or post mortem destruction of tests, mainly in the stations GB6 (15 species/taxa) and GB1 (8 species). In stations GB4 and GB8, this difference is very small since they display much reduced values of FD. Both stations are located in areas of high natural environmental stress. In fact, GB4 near the rivers of the Guapimirim Apa (at NE area) displays the lowest salinities and high TOC content.

Relatively high S3 and PI values (parameters obtained by Rock-Eval pyrolysis analysis) related to a high production of $\mathrm{CO}_{2}$ from organic matter degradation and to contamination by oil released probably by boats, respectively were found at station GB7 by Delavy et al. (2016). According to Martins et al. (2016c), the organic matter in this area may be at a reduction phase of the sediments to which are associated relatively high concentrations of metals. This set of characteristics should negatively affect and prevent the development of large foraminiferal populations.

\subsection{Characteristics of LFA and DFA in 63-150 um sediment fraction}

Very low FD were found in the stations GB8 and GB9 both in LFA and DFA in the 63-150 $\mu \mathrm{m}$ sediment fraction and have not therefore been considered in this analysis. The FD of dead specimens identified in the 63-150 $\mu \mathrm{m}$ (DFFF) is two to four times higher than the LFFF, except in GB6 where it is similar in both assemblages (Appendices 5-6). This difference is highest in GB1. This difference might be ascribed to the accumulation of more generations in the DFFF. The FD of DFA and DFFF is similar in GB3 and GB5 but is two or three times higher in the DFA than in DFFF in the other stations. These results might be related to a better preservation of the tests with larger dimension than the smaller one. Similarly, the FD of LFA and LFFF is similar in GB3 and GB5 stations but it is two or three times higher for the LFA in the other stations, except in GB7 where it is 19 times higher. This difference might be related to differential time reproduction. However, in all stations the values of $\mathrm{J}^{\prime}$ and $\mathrm{H}^{\prime}$ are higher for DFFF and LFFF than for DFA and LFA, respectively. These results may indicate either small dimension (dwarfism) or died before reaching larger dimension (adult stage). 


\subsection{Characteristics of LFA and DFA in different sediment fractions}

On the basis of the species comparison between the LFA and DFA in different sediment fractions is possible to highlight that: i) Stainforthia fusiformis, Rosalina globularis, Quinqueloculina laevigata, Ophthalmidium balkwilli, Nonionella opima, Lagena striata and Hopkinsina pacifica only occurred as DFFF; ii) Trocbulina dimidiatus, Quinqueloculina seminula, Ammotium salsum only occurred as LFFF; and iii) Spirobolivina curta, Reophax curtus, Nonionella atlantica, Miliolids (partially dissolted), Fursenkoina pontoni, Fursenkoina conspiqua, Elphidium williamsoni, Elphidium incertum, Elphidium gunteri, Cribroelphidium poeyanum and Cribroelphidium albiumbilicatum were found only as FMF.

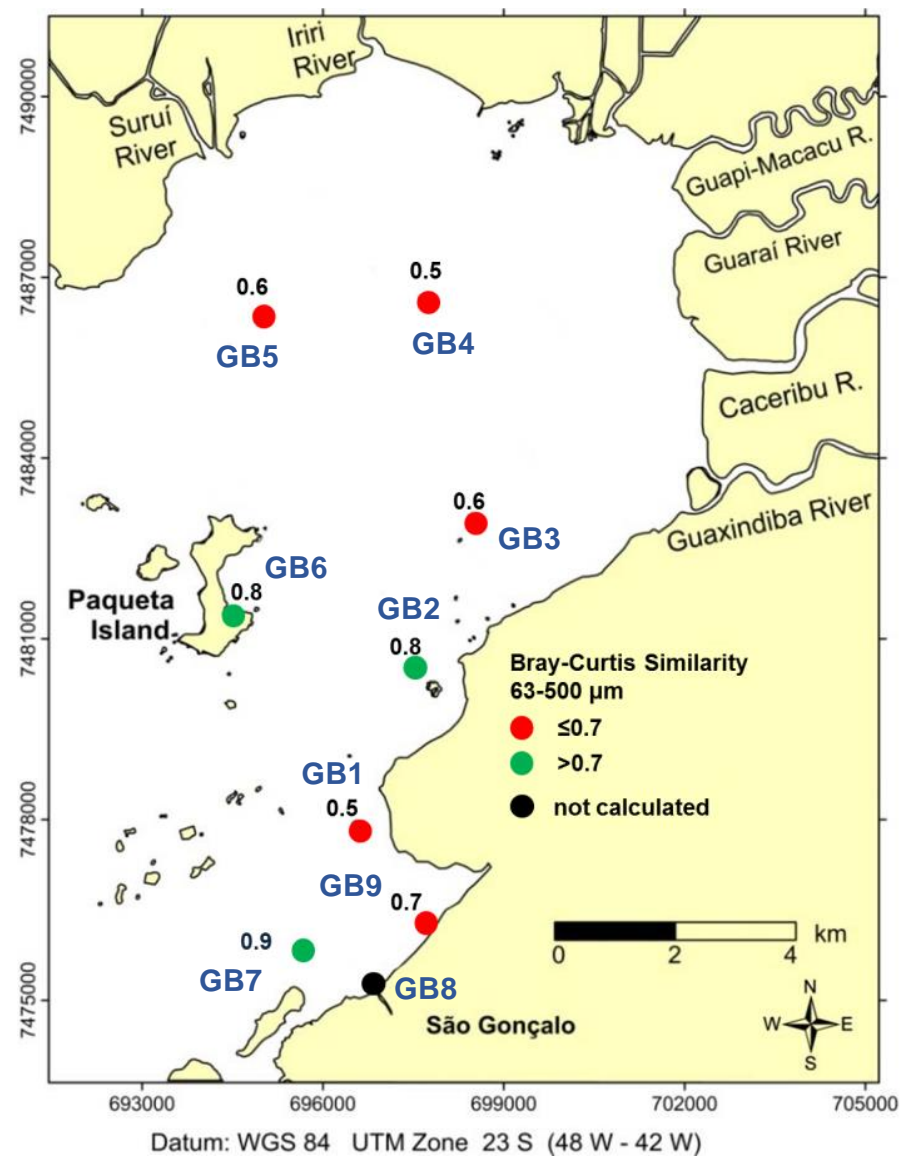

A
These preliminary results allow us to speculate that the presence of $T$. dimidiatus and $Q$. seminula only in the LFA (representing $0.3-1.3 \%$ of the assemblage) might be linked to a reproduction event, for instance in station GB6. At this station, FD is relatively high but being located inside a harbor for small boats at Parati Island the action of the currents is calm and erosion effects caused by hydrodynamic effects is unlikely. The absence of these species in the DFA may be due to differential destruction of tests. Ammotium salsum was only found in the LFA of GB7 station, where FD is reduced. The absence of this species in the DFA and the similar proportion of LFFF and DFFF in this station might be associated with differential destruction and/or remobilization of tests by hydrodynamic action or other taphonomic effects.

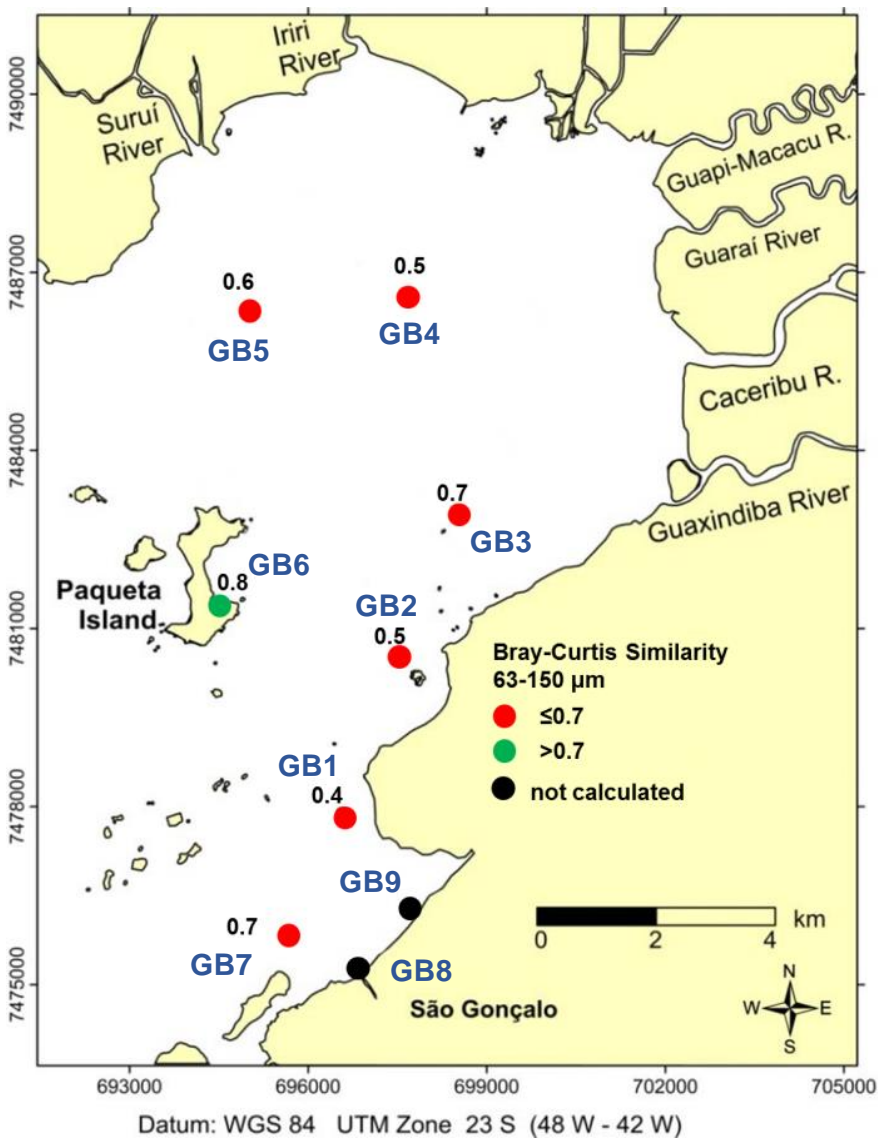

B

Fig. 7. Bray Curtis similarity between the dead and living assemblages of foraminifera, in sediment fractions A. 63-500 $\mu \mathrm{m}$ and; B. $63-$ $150 \mu \mathrm{m}$. Legend: stations GB1 to GB9 in blue letters; numbers in black bold values of Bray Curtis similarity. 
The presence in DFFF of species commonly associated with the open ocean environments such as $S$. fusiformis, $R$. globularis, Q. laevigata, O. balkwilli, N. opima, L. striata and $H$ pacifica should indicate the deposition of allochthonous material transported by tidal currents. This is also supported by the occurrence of some species (C. albiumbilicatum, $E$. williamsoni, $N$. atlantica and $R$. curtus) only in the sediment fraction $>125 \mu \mathrm{m}$. According to the results of the CA (Fig. 6 ), in the stations GB6 and GB3 the LFA and DFA of the 63-150 $\mu \mathrm{m}$ and 150-250 $\mu \mathrm{m}$ sediment fractions, respectively, are the most similar.

The FCF in a sufficient number (presence of at least 100 specimens in the analyzed amount of sediment) to characterize both the LFA and the DFA were only found in GB1 station and to characterize the DFA only in GB2. These results suggest that the environmental conditions remained stable for a relatively long period in GB1, allowing the growth of the juveniles. However, the LFA and DFA of 250$500 \mu \mathrm{m}$ sediment fraction differ in composition from that found $63-250 \mu \mathrm{m}$ and $125-250 \mu \mathrm{m}$ sediment fractions. These results should indicate that that only some species were capable of reaching relatively large dimension in the study area.

\subsection{Factors controlling the DFA and LFA similarity in the NE sector of Guanabara Bay}

Stations GB2, GB6, GB7 and GB9, where the Bray Curtis similarities between the DFA and LFA (Fig. 7A) are the highest, were associated with relatively good water conditions based on as oxygenation, salinity (close to oceanic one) and $\mathrm{pH}$ (Appendix 6; Table 3). These stations are less impacted by organic matter and therefore possibly less prone to dysoxic conditions in the subsurface pore-water. They are however affected by intermediate contamination by metals (Tables 1 and 2). On the other hand, stations GB1 and GB4 with relatively lower Bray Curtis similarity between the DFA and LFA $(63-500 \mu \mathrm{m})$ (Fig. 7A) are characterized by high stress conditions caused by the accumulation of organic matter, but not by metals (Tables 1-3).

The highest Bray-Curtis similarities between the DFFF and LFFF were found at GB3, GB6 and GB7 (Fig. 7B) and the lowest ones at stations GB1, GB2 and GB4 (Fig. 7B). Both groups of stations present the same general environmental characteristics observed for the maximum and minimum similarities between DFA and LFA, respectively (Table 3), except for $\mathrm{Zn}$. The lowest concentrations of $\mathrm{Zn}$ were found in stations with the highest values of Bray-Curtis similarity. These results indicate that the greatest differences between the living and dead assemblages are not caused by the increasing of metals concentrations in this low polluted area but by the sharp increase of the sedimentary organic matter content.

\section{Conclusion}

The results of this work suggest considerable differences between the LFA and DFA at some stations. In particular, the DFA is not constantly equivalent to the LFA in abundance and diversity; the DFA is not more abundant than the LFA in all the stations and; the proportion between both assemblages vary in the studied stations.

The highest similarity between the LFA and DFA occurs where the water quality is better and the sediment has lower organic matter content. The moderate increase in metal concentrations does not appear to cause marked differences in the composition of the LFA and DFA in the NE region of GB. These differences seem to be caused by differential dissolution of the tests, but also, at least in some places, by the deposition of allochthonous materials from nearby areas by tidal currents. The instability of the environmental parameters seems to block the growth of the foraminifera populations and individuals, consisting essentially of organisms tolerant to the instability of the environment and to the stress caused by the processes related to the degradation of the organic matter.

In this way, the present methodology to be applied in ecology works that have as objective of the environmental evaluation of the Guanabara Bay or of another coastal or oceanic system impacted by organic matter, is the use of living assemblages of benthic foraminifera.

\section{Acknowledgment}

This work was also partially supported by funds of the UID/GEO/04035/2013 (FCT, Portugal). The authors would like to thank to CAPES for the Master Fellowship of Pierre Belart and to the PhD Fellowship of Anita Pinto and to FAPERJ of IC Fellowship of Maria Clara; the Universidade Pedagógica of Mozambique and to Universidade de Aveiro, Portugal by the Master Fellowship of Assane Pena.

Appendices 1-6 are attached as supplementary materials (SM1SM6) in http://www.epublicacoes.uerj.br/index.php/jse/article/view/22534 


\section{References}

Aguiar, V.M. de C., Baptista Neto, J.A.B., Rangel, C.M., 2011. Eutrophication and hypoxia in four streams discharging in Guanabara Bay, RJ, Brazil, a case study. Marine Pollution Bulletin 62 doi.org/10.1016/j.marpolbul.2011.04.035

Alve, E., Olsgardt, F. 1999. Benthic foraminiferal colonisation in experiments with copper-contaminated sediments. Journal of Foraminiferal Research 29, 186-195.

Alve, E. 1995. Benthic foraminiferal responses to estuarine pollution: a review. Journal of Foraminiferal Research 25, 190203.

Alve, E. 1991. Benthic foraminifera in sediment cores reflecting heavy metal pollution in Soerfjord, Western Norway. Journal of Foraminiferal Research 21, 1-19.

Andrade, A. C., Santos, S.R., Verani, J.R., Vianna, M., 2016. Guild composition and habitat use by Tetraodontiformes (Teleostei, Acanthopterygii) in a south-western Atlantic tropical estuary. Journal of the Marine Biological Association of the United Kingdom $96 \quad$ (6), 1251-1264. doi.org/10.1017/S0025315415001368

Baptista Neto, J.A., Smith, B.J., Mcalliste, J.J., 2000. Heavy metal concentrations in surface sediments in a nearshore environment, Jurujuba Sound, SE Brazil. Environmental Pollution 109 (1), 1-9. doi.org/10.1016/S0269-7491(99)00233$\mathrm{X}$

Benhard, J.M., Sen Gupta, B., 1999. Foraminifera of oxygen depleted environments. In: Sen Gupta, B. (Ed.), Modern Foraminifera, New York: Kluwer Academic Publishers, p. 201216.

Boltovskoy, E., Giussani, G., Watanabe, S., Wright, R., 1980. Atlas of benthic shelf foraminifera of the Southwest Atlantic. Dr. W. Junk b.v., Publishres, The Hague, 147 pp., pl. 36.

Boltovskoy, E., 1956. Applications of chemical ecology in the study of foraminifera. Micropaleontology 2, 321-325.

Bonecker, S.L.C., Dias, C.O., Fernandes, L.D., Araújo, A.V., 2012. Avaliação da comunidade mesozooplanctônica. In: Meniconi, M.F.G., Silva, T.A., Fonseca, M.L., Lima, S.O.F., Lima, E.F.A., Lavrado, H.P., Figueiredo, A.G. (Eds.), Baía de Guanabara. Síntese do Conhecimento Ambiental. Vol. II. Biodiversidade. PETROBRAS, Rio de Janeiro, pp. 99-145.

Borja, Á., Franco, J., Valencia, V., Bald, J., Muxika, I., Belzunce, M.J., Solaun, O., 2004a. Implementation of the European Water Framework Directive from the Basque country (northern Spain): a methodological approach (viewpoint). Marine Pollution Bulletin 48, 209-218. doi: 10.1016/j.marpolbul.2003.12.001

Borja, Á., Franco, J., Muxika, I., 2004b. The biotic indices and the Water Framework Directive: the required consensus in the new benthic monitoring tools (correspondence). Marine Pollution Bulletin 48, 405-408.
Borja, Á., Muxika, I., Franco, J., 2003. The application of a Marine Biotic Index to different impact sources affecting soft-bottom benthic communities along European coasts. Marine Pollution Bulletin 46, 835-845. doi:10.1016/S0025-326X(03)00090-0

Borja, Á., Franco, J., Pérez, V., 2000. A marine biotic index to establish the ecological quality of soft-bottom benthos within European estuarine and coastal environments. Marine Pollution Bulletin 40, 1100-1114. doi.org/10.1016/S0025326X(00)00061-8

Carreira, R.S., Wagener, A.L., Readman, J.W., Fileman, T.W., Macko, S.A., Veiga, A., 2002. Changes in the sedimentary organic carbon pool of a fertilized tropical estuary, Guanabara Bay, Brazil: an elemental, isotopic and molecular marker approach. Marine Chemistry 79, 207-227. doi.org/10.1016/S0304-4203(02)00065-8

Caruso, A., Cosentino, C., Tranchina, L., Brai, M., 2011. Response of benthic foraminifera to heavy metal contamination in marine sediments (Sicilian coasts, Mediterranean Sea). Chemistry and Ecology 27, 9-30. doi.org/10.1080/02757540.2010.529076

Casamajor, M.N., Debenay, J.P., 1995. Les Foraminifères, bioindicateurs des environnements paraliques: réaction à divers types de pollution dans l'estuaire de l'Adour. In: ANPP Colloque Internacional: Marqueurs Biologiques de Pollution, Chinon, 1995, p. 371-378.

Clemente, I.M.M.M., Silva, F.S., Laut, L.L.M., Frontalini, F., Costa, V.L., Rodrigues, M.A.C., Pereira, E., Bergamaschi, S., Filho, J.G.M., Martins, M.V.A., 2015. Biochemical Composition and Foraminiferal Content of Sediments for Determining Bottom Sector Environments in Guanabara Bay (Rio de Janeiro, Brazil). Journal of Coastal Research 315, 1190-1204.

Culver, S.J, Buzas, M.A, 1995. The effects of anthropogenic habitat disturbance, habitat destruction, and global warming on shallow marine benthic foraminifera. Journal of Foraminiferal Research 25, 204-211.

Debenay, J.-P., Tsakiridis, E., Soulard, R., Grossel, H., 2001. Factors determining the distribution of foraminiferal assemblages in Port Joinville Harbour (lle d'Yeu, France): the influence of pollution. Marine Micropaleontology 43, 75-118. doi: 10.1016/S0377-8398(01)00023-8

Debenay, J-.P, Guillou, J.J., Redois, F., Geslin, E., 2000. Distribution trends of foraminiferal assemblages in paralic environments: a base for using foraminifera as bioindicators. In: Martin, R.E. (Ed.), Environmental Micropaleontology, Topics in Geobiology, 15, New York: Kluwer Academic Publishers, p. 39-67.

Delavy, F.P., Figueiredo Jr., A.G., Martins, M.V.A., Rodrigues, R., Pereira, E., Brito, M.A.R.C., Fonseca, M.C.M., Laut, L.L.M., Bergamaschi, S., Miranda, P., Rodrigues, M.A.C., 2016. Highresolution acoustic mapping of gas charged sediments and living benthic foraminifera assemblages from the NE region of the Guanabara Bay (RJ, Brazil). Journal of Sedimentary Environments 1 (3), 367-392. doi: 10.12957/jse.2016.26281 
Dimiza, M.D., Triantaphyllou, M.V., Koukousioura, O., Hallock, P., Simboura, N., Karageorgis, A.P., Papathanasiou, E., 2016 a. The Foram Stress Index: a new tool for environmental assessment of soft-bottom environments using benthic Foraminifera. A case study from the Saronikos Gulf, Greece, Eastern Mediterranean. Ecological Indicators 60, 611-621. doi.org/10.1016/j.ecolind.2015.07.030

Dimiza, M.D., Koukousioura, O., Triantaphyllou, M.V., Dermitzakis, M.D., 2016b. Benthic foraminiferal assemblages from coastal environments of the Aegean Sea (Greece). Revue de Micropaléontologie 59, 19-32. doi.org/10.1016/j.revmic.2015.10.002

Donnici, S., Serandrei-Barbero, R., Bonardi, M., Sperle, M., 2012. Benthic foraminifera as proxies of pollution: The case of Guanabara Bay (Brazil). Marine Pollution Bulletin 64, 20152028. doi.org/10.1016/j.marpoGBul.2012.06.024

Eichler, B.B., Debenay, J-.P., Bonetti, C., Duleba, W., 1995. Répartition des foraminifères benthiques dans la zone sudouest du système estuarien-lagunaire d'Iguape-Cananéia (Brésil). Boletim do Instituto Oceanográfico 43, 1-17. doi.org/10.1590/S0373-55241995000100001

Elliott, M., Quintino, V., 2007. The estuarine quality paradox, environmental homeostasis and the difficulty of detecting anthropogenic stress in naturally stressed areas. Marine Pollution Bulletin 54, 640-645. doi: 10.1016/j.marpolbul.2007.02.003

Elliott, M., McLusky, D.S., 2002. The need for definitions in understanding estuaries. Estuarine Coastal Shelf Science 55, 815-827. doi: 10.1006/ecss.2002.1031

Ellison, R., Broome, R., Ogilvie, R., 1986. Foraminiferal response to trace metal contamination in the Patapsco River and Baltimore Harbour, Maryland. Marine Pollution Bulletin 17, 419-423. doi:10.1016/0025-326X(86)90321-8

Figueiredo, A.G., Toledo, M.B., Cordeiro, R.C., Gogoy, J.M.O., Silva, F.T., Vasconcelos, S.C., Santos, R.A., 2014. Linked variations in sediment accumulation rates and sea-level in Guanabara Bay, Brazil, over the last 6000 years. Palaeogeography, Palaeoclimatology, Palaeoecology 415, 8390.

Filippo, A.M., Figueired Jr, F.G., 2012. 2. Caracterização Hidrodinâmica. In Meniconi, M.F.G., Silva, T.A., Fonseca, M.L., Lima, S.O.F., Lima, E.F.A., Lavrado, H.P., Figueredo Jr., A.G. (eds), Baia de Guanabara, Síntese do Conhecimento Ambiental, Ambiente e Influência Antrópica, vol. 1 Petrobras, Rio de Janeiro, pp. 44-47.

Frontalini, F., Coccioni, R., 2008. Benthic foraminifera for heavy metal pollution monitoring: a case study from the central Adriatic Sea coast of Italy. Estuarine, Coastal and Shelf Science 76, 404-417. doi.org/10.1016/j.ecss.2007.07.024

Gomes, E.A.T., Areas, M.O., 2012. Caracterização do protozooplâncton. In: Meniconi, M.F.G., Silva, T.A., Fonseca, M.L., Lima, S.O.F., Lima, E.F.A., Lavrado, H.P., Figueiredo,
A.G. (Eds.), Baía de Guanabara. Síntese do Conhecimento Ambiental. Vol. II. Biodiversidade. PETROBRAS, Rio de Janeiro, pp. 67-97.

Hammer, Ø., Harper, D.A.T., Ryan, P.D., 2001. PAST: Paleontological statistics software package for education and data analysis. Palaeontologia Electronica. 4(1), 9 pp. http://palaeo-electronica.org/2001 1/past/issue1 01.htm

Hyland, J., Balthis, L., Karakassis, I. Magni, P., Petrov, A., Shine, J., Vestergaard, O., Warwick, R., 2005. Organic carbon content of sediments as an indicator of stress in the marine benthos. Marine Ecology Progress Series 295, 91-103. doi:10.3354/meps295091

Kfouri, P.B.P., Figueira R.C.L., Figueiredo A.M.G., Souza S.H.M., Eichler B.B., 2005. Metal levels and foraminifera occurrence in sediment cores from Guanabara Bay, Rio de Janeiro, Brazil. Journal of Radioanalytical and Nuclear Chemistry 265 (3), 459466. doi: 10.1007/s10967-005-0849-8

Kjerfve, B., Ribeiro, C.H.A., Dias, G.T.M., Filipo, A.M., Quaresma, V.S., 1997. Oceanographic characteristics of an impacted coastal bay: Baía de Guanabara, Rio de Janeiro, Brazil. Continental Shelf Research 17, 1609-1643. Doi: 10.1016/S0278-4343(97)00028-9

Jablonski, S., Azevedo, A.F., Moreira, L.H.A., 2006. Fisheries and conflicts in Guanabara Bay, Rio de Janeiro, Brazil. Brazilian Archives of Biology and Technology 49, 79-91. doi.org/10.1590/S1516-89132006000100010

Laut, L.L.M., Clemente, I.M.M.M., Belart, P., Martins, M.V.A., Frontalini, F., Laut, V.M., Gomes, A., Boski, T., Lorini, M.L., Fortes, R.R., Rodrigues, M.A.C., 2016. Multiproxies (benthic foraminifera, ostracods and biopolymers) approach applied to identify the environmental partitioning of the Guadiana River Estuary (Iberian Peninsula). Journal of Sedimentary Environments 1(2), 184-201. doi: 10.12957/jse.2016.22534

Laut, L.L.M., Laut, V.M., Silva, F.S., Figueiredo Jr., A.G., 2011. Modern diatom distributions in Guanabara Bay sedimend and oceanic areas, Rio de Janeiro (Brazil). Anuário do Instituto de Geociências - UFRJ 34, 64-87.

Machado, W., Carvalho, M.F., Santelli, R.E., Maddock, J.E.L., 2004. Reactive sulfides relationship with metals in sediments from an eutrophicated estuary in southeast Brazil. Marine Pollution Bulletin 49, 89-92. doi: 10.1016/j.marpolbul.2004.01.012

Martins, M.V.A., Hohenegger, J., Frontalini, F., Miranda, P., Rodrigues, M.A.C., Dias, J.M.A., 2016a. Comparison between the dead and living benthic foraminiferal assemblages in Aveiro Lagoon (Portugal). Palaeogeography, Palaeoclimatology, Palaeoecology 455 (1) 16-32. doi:10.1016/j.palaeo.2016.05.003

Martins, M.V.A., Helali, M.A., Zaaboub, N., BenOmrane, I.B. Frontalini, F., Reis, D., Portela, H., Clemente, I.M.M.M., Nogueira, L., Pereira, E., Miranda, P., El Bour, M., Aleya, L., 2016b. Organic matter quantity and quality, metals availability and foraminifera assemblages as environmental proxy applied 
to the Bizerte Lagoon (Tunisia). Marine Pollution Bulletin 105, 161-179. doi.org/10.1016/j.marpoGBul.2016.02.032.

Martins, M.V.A., Laut, L.L.M., Frontalini, F., Sequeira, C., Rodrigues, R., Fonseca, M.C.F., Bergamashi, S., Pereira, E., Delavy, F.P., Figueiredo Jr., A.G., Miranda, P., Terroso, D., Luís Pena, A.L., Laut, V.M., Figueira, R., Rocha, F., 2016c. Controlling Factors on the abundance, diversity and size of living benthic foraminifera in the NE Sector of Guanabara Bay (Brazil). Journal of Sedimentary Environments 1(4), 401-418. doi: $10.12957 /$ jse.2016.26872

Martins, M.V.A. Zaaboub, N., Aleya, L., Frontalini, F., Pareira, E., Miranda, P., Mane, M., Rocha, F., Laut, L., El Bour, M. 2015. Environmental quality assessment of Bizerte Lagoon (Tunisia) using living foraminifera assemblages and a multiproxy approach. PLoS ONE. doi.10.1371/journal.pone.0137250

Martins, V.A., Frontalini, F., Tramonte, K.M., Figueira, R.C.L., Miranda, P., Sequeira, C., Fernández-Fernández, S., Dias, J.A., Yamashita, C., Laut, L.M., Sobrinho, F., Rodrigues, M.A., Bernardes, C., Nagai, R., Sousa, S.S.M., Mahiques, M., Rubio, B., Bernabeu, A., Rey, D., Rocha, F., 2013. Assessment of the health quality of Ria de Aveiro (Portugal): heavy metals and benthic foraminifera. Marine Pollution Bulletin 70, 18-33. doi: 10.1016/j.marpolbul.2013.02.003.

McCrone, A.W., Schafer, C.T., 1966. Geochemical and sedimentary environments of foraminifera in the Hudson River estuary, New York. Micropaleontology 12, 505-509.

Mendes, C.L.T., Tavares, M., Soares-Gomes, A., 2007. Taxonomic sufficiency for soft bottom subllitoral mollusks assemblages in a tropical estuary, Guanabara Bay, Southeast Brazil. Marine Pollution Bulletin 54, 377-384. doi:10.1016/j.marpolbul.2006.08.026

Mendes, C.L.T., Soares-Gomes, A., Tavares, M., 2006. Seasonal and spatial distribution of sublittoral soft-bottom mollusks assemblages at Guanabara Bay, Rio de Janeiro, Brazil. Journal of Coastal Research 39 (SI), 1877-1881.

Müller, G., 1981. Die Schwermetallbelastung der Sedimente des Neckars und seiner Nebenflüsse: Eine Bestandsaufnahme. Chemical Zeitung 105, 157-164.

Murray, J.W., 2006. Ecology and applications of benthic foraminifera, Cambridge, UK, Cambridge University Press, 426p.

Murray, J.W., 1991. Ecology and palaeoecology of benthic foraminifera. London, Longman Scientific \& Technical, 397 pp.

Muxika, I., Borja, A., Bonne, W., 2005. The suitability of the marine biotic index (AMBI) to new impact sources along European coasts. Ecological Indicators 5, 19-31. doi:10.1016/j.ecolind.2004.08.004

Paranhos, R. Andrade, L., 2012. Caracterização fisico-quimica da coluna d'água e a qualidade das águas. In Meniconi, M.F.G., Silva, T.A., Fonseca, M.L., Lima, S.O.F., Lima, E.F.A., Lavrado, h.P., Figueredo Jr., A.G. (eds), Baia de Guanabara,
Sintese do Conhecimento Ambiental, Ambiente e Influência Antrópica, vol. 1 Petrobras, Rio de Janeiro, pp. 60-79.

Pereira, E.R.M., Eichler, P.P.B., Eichler, B.B., 2006. Foraminifera as proxies in environmental diagnostic in Guanabara Bay, RJ. Journal of Coastal Research, SI 39, 1395-1398.

Pires, I.O., 2010. Manguezais da região do recôncavo da Baía de Guanabara: revisita através dos mapas. Revista de Gestão Costeira Integrada / Journal of Integrated Coastal Zone Management 2, 1-9.

Poag, W., 2015. Benthic Foraminifera of the Gulf of Mexico: Distribution, Ecology, Paleoecology. Texas A\&M University Press, $256 \mathrm{p}$.

Quaresma, V.S., Dias, G.T.M., Baptista Neto, J.A., 2000. Caracterização da ocorrência de padrões de sonar de varredura lateral e sísmica de alta frequência $(3,5$ e 7,0 kHz) na porção sul da Baía de Guanabara - RJ Revista Brasileira de Geofísica, 18 (2000), pp. 201-214.

Samir, A.M., 2000. The response of benthic foraminifera and ostracods to various pollution sources: a study from two lagoons in Egypt. Journal of Foraminiferal Research 30, 83-98.

Santi, L., Tavares, M., Omena, E.P., 2006. Patterns of species richness and species density of sublittoral soft-bottom polychaetes in a gross polluted urban bay: Guanabara Bay, Rio de Janeiro, Brazil. Journal of Coastal Research 39 (SI), 1127 1131.

Schafer, C.T., 1973. Distribution of foraminifera near pollution sources in Chaleur Bay. Water Air and Soil Pollution 2, 219233.

Schönfeld, J., 2012. History and development of methods in Recent benthic foraminiferal, 2012. Journal of Micropalaeontology 2, 31, 53-72. doi.org 10.1144/0262821X11-008.

Schönfeld, J., Alve, E., Geslin, E., Jorissen, F., Korsund, S., Spezzaferri, S., 2012. The FOBIMO (FOraminiferal BIoMOnitoring) initiative - Towards a standardised protocol for soft-bottom benthic foraminiferal monitoring studies. Marine Micropaleontology 94-95, 1-13. doi: 10.1016/j.marmicro.2012.06.001

Seiglie, G.A., 1968. Foraminiferal assemblages as indicators of high organic carbon contents in sediments and of polluted waters. AAPG Bulletin 52, 2231-2241.

Soares-Gomes, A., da Gama, B.A.P., Baptista Neto, J.A., Freire, D.G., Cordeiro, R.C., Machado, W., Bernardes, M.C., Coutinho, R., Thompson, F.L., Pereira, R.C., 2016. An Environmental Overview of Guanabara Bay, Rio de Janeiro. Regional Studies in Marine Science. doi: 10.1016/j.rsma.2016.01.009.

Soares-Gomes, A., Mendes, C.L.T., Tavares, M., Santi, L., 2012. Taxonomic sufficiency of polychaete taxocenes for estuary monitoring. Ecological Indicators 15, 149-156.

Suchy, K.D., Avila, T.R., Dower, J.F., Bianchini, A., Figueiredo, G.M., 2016. Short-term variability in chitobiase-based 
planktonic crustacean production rates in a highly eutrophic tropical estuary. Marine Ecology Progress Series 545, 77-89. doi.org/10.3354/meps11637

Sutherland, R.A. 2000, Bed sediment-associated trace metals in an urban stream, Oahu, Hawaii. Environmental Geology 39, 39 (6), 611-627. doi:10.1007/s002540050473

Tomas, E., Gapotchenko, T., Varekamp, E.C., Mecray, E.L., Buchholtz ten Brink, M.R., 2000. Benthic Foraminifera and Environmental Changes in Long Island Sound. Journal of Coastal Research 16 (3), 641-655.

Van der Ven, P.H., Soares-Gomes, A., Tavares, M., 2006. Taxocene of Crustacea at a highly impacted bay: Guanabara Bay, southeastern Brazil. Journal of Coastal Research 39 (SI), 1135-1139.

Van der Zwann, G.J., 2000. Variation in natural vs. anthropogenic eutrophication of shelf areas in front of major rivers. In: Martin, R.E (Ed.), Environmental Micropaleontology, Topics in Geobiology 15, New York: Kluwer Academic Publishers, p. 385-404.

Vianna, M., Andrade-Tubino, M.F., Keunecke, K.A., Andrade, A.C., Silva, D.R., Padula, V., 2012. Estado atual de conhecimento sobre a ictiofauna. M.F.G. Meniconi, T.A. Silva, M.L. Fonseca, S.O.F. Lima, E.F.A. Lima, H.P. Lavrado, A.G. Figueiredo (Eds.), Baía de Guanabara. Síntese do Conhecimento Ambiental. Vol. II. Biodiversidade, PETROBRAS, Rio de Janeiro (2012), pp. 170-195.

Vilela, C.G., Figueira, B.O., Macedo, M.C., Baptista Neto, J.A., 2014. Late Holocene evolution and increasing pollution in Guanabara Bay, Rio de Janeiro, SE Brazil. Marine Pollution Bulletin 79, 175-187. doi: 10.1016/j.marpolbul.2013.12.020

Vilela, C.G., Batista, D.S., Baptista Neto, J.A., Ghiselli, R.O., 2011. Benthic foraminifera distribution in a tourist lagoon in Rio de Janeiro, Brazil: A response to anthropogenic impacts. Marine Pollution Bulletin 62, 2055-2074.

Vilela, C.G., Figueira, B.O., Baptista Neto, J.A., 2007. Ecologia e paleocologia na Baía de Guanabara, Rio de Janeiro, durante os últimos 6000 anos, com base em variações na assembléia de foraminíferos bentônicos. Paleontologia: Cenários da Vida. Editora Interciência 2, 345-361.

Vilela, C.G., Batista, D.S., Baptista-Neto, J.A., Crapez, M., Mcallister, J.J., 2004. Benthic foraminifera distribution in high polluted sediments from Niterói Harbor (Guanabara Bay), Rio de Janeiro, Brazil. Anais da Academia Brasileira de Ciências 76, 161-171.

Villac, M.C., Tenenbaum, D.R., 2010. The phytoplankton of Guanabara Bay, Brazil. I. Historical account of its biodiversity. Biota Neotropica 10, 271-293. doi.org/10.1590/S167606032010000200030

Wagener, A.L.R., 1995. Burial of organic carbon in estuarine zones- estimates for Guanabara Bay, Rio de Janeiro. Química Nova 18, 534-535.

Watkins, J.G., 1961. Foraminiferal ecology around the Orange County, California, ocean sewage outfall. Micropaleontology 7, 199-206.

Xavier de Brito, A.P., Brüning, I.M.R., Moreira I., 2002. Chlorinated pesticides in mussels from Guanabara Bay, Rio de Janeiro, Brazil. Marine Pollution Bulletin 44, 7181 .

Yanko, V., Arnold, A.J., Parker, W.C., 1999. Effects of marine pollution on benthic Foraminifera. In: Sen Gupta, B. (Ed.), Modern Foraminifera, New York: Kluwer Academic Publishers, p. 217-235.

Yanko, V., Ahmad, M., Kaminski, M., 1998. Morphological deformities of benthic foraminiferal tests in response to pollution by heavy metals: implications for pollution monitoring. Journal of Foraminiferal Research 28, $177-$ 200 .

Yanko, V., Kronfeld, J., Flexer, A., 1994. Response of benthic foraminifera to various pollution sources: implications for pollution monitoring. Journal of Foraminiferal Research 24, 1-17. 